DOI: 10.32089/WBH.PHW.2020.3(273).0002

orcid.org/0000-0001-8838-5651

LESZEK KANIA

(Uniwersytet Zielonogórski)

\title{
Stosunek społeczeństwa polskiego i mniejszości narodowych do obowiązku służby wojskowej w czasie wojny z Rosją bolszewicką (luty 1919 - listopad 1920)
}

\section{Wprowadzenie}

Wojna z Rosją bolszewicką o niepodległość z lat 1919-1921 stale przyciąga uwagę badaczy i czytelników. Prócz monografii niektórych związków operacyjnych, dywizji, brygad, pułków, rodzajów broni i służb systematycznie przybywa też publikacji z opisem przebiegu operacji wojennych, szlaków bojowych wybranych formacji, biografii wyższych dowódców i zbiorów dokumentów źródłowych ${ }^{1}$. Dopełnieniem odtwarzanego z wielkim trudem

\footnotetext{
${ }^{1}$ Zob. Odrodzenie Wojska Polskiego 1918-1921 w materiałach CAW, pod red. A. Wesołowskiego, Warszawa 2008; Bitwa niemeńska 29 VIII - 18 X 1920. Dokumenty operacyjne, cz. 1: 29 VIII-19 IX, oprac. zesp. pod kier. M. Tarczyńskiego, Warszawa 1998; cz. 2: 20 IX-18 X, oprac. eidem, Warszawa 1999; Bitwa lwowska 25 VII - 18 X 1920. Dokumenty operacyjne, cz. 1: 25 VII - 5 VIII, oprac. eidem, Warszawa 2002 oraz cz. 2: 6-20 VIII, Warszawa 2004; Bitwa warszawska 13-28 VIII 1920. Dokumenty operacyjne, cz. 1: 3-17 VIII, oprac. eidem, Warszawa 1995; cz. 2: 17-28 VIII, oprac. eidem, Warszawa 1996; N. Davies, Orzeł biały, czerwona gwiazda. Wojna polsko-bolszewicka 1919-1920, tłum. A. Pawelec, Kraków 2011; T. Grzegorczyk, 6 Armia Wojska Polskiego w 1920 r., Toruń 2009; K. Klimaszewski, M. Pakuła, Bitwa Warszawska 1920 r. Jabłonna, Legionowo, Nieporęt, Serock, Wieliszewo, Legionowo 2016; Z. M. Musialik, Wojna polsko-bolszewicka 1919-1920, Włocławek 1994; G. Nowik, Zanim złamano „Enigmę". Polski radiowywiad podczas wojny z bolszewicką Rosją 1918-1920, Warszawa 2004; J. Odziemkowski, Piechota polska w wojnie $z$ Rosja bolszewicka 1919-1920, Warszawa 2010; idem, Wojsko Polskie w latach 1918-1920 (organizacja i struktura), Warszawa 2001; Bitwa Warszawska 1920 roku w obronie niepodległości, pod red. idem, Warszawa 2006; M. Wrzosek, Wojsko Polskie i operacje wojenne lat 1918-1921, Białystok 1988; L. Wyszczelski, Wojna polsko-rosyjska 1919-1920, t. 1-2, Warszawa 2010; idem, Warszawa 1920, Warszawa
} 
obrazu pola walki są monografie, studia i przyczynki dotyczące organizacji i działalności żandarmerii, wojsk etapowych, piechoty, artylerii, lotnictwa, sądownictwa, duszpasterstwa i służby zdrowia. Januszowi Szczepańskiemu i badaczom nowego pokolenia zawdzięczamy szerszą wiedzę na temat politycznych postaw społeczeństwa polskiego i mniejszości narodowych w czasie tej wojny. Publikacje wyników badań o masowym zjawisku kolaboracji z najeźdźcą ukazały się dopiero po odzyskaniu wolności badań naukowych w ostatniej dekadzie XX w. ${ }^{2}$ Z kolei zagadnienia organizacji i funkcjonowania administracji wojskowej i działalności służb tyłowych poruszane są w monografiach Okręgów Generalnych (OGen.) i wielkich jednostek. Gorzej przedstawia się stan badań nad zagadnieniem wymuszania posłuszeństwa wobec rozkazu i rozkazodawców, nad zjawiskiem dezercji, uchylania się od służby wojskowej i zwalczania czynów godzących w wewnętrzną spoistość wojska (karalne samouszkodzenia, odmowa wykonania rozkazu, niewykonanie rozkazu zgodnie z jego treścią, samowolne zejście z linii bojowej przez aparat dowodzenia), Żandarmerią Polową, defensywą (kontrwywiad) i sądami polowymi ${ }^{3}$. Spektakularne sprawy sądowe dotyczące egzekwowania dyscypliny wojskowej i wymierzania kar sprawcom przestępstw wojskowych znamy

1997; P. Żarkowski, Polska sztuka wojenna w okresie bitwy warszawskiej. Front Środkowy w działaniach manewrowych w sierpniu 1920 roku, Warszawa 2004.

2 J. Szczepański, Społeczeństwo Polski w walce z najazdem bolszewickim 1920 roku, Warszawa-Pułtusk 2000; idem, Wojna 1920 na Mazowszu i Podlasiu, Warszawa-Pułtusk 1995; idem, Wojna 1920 roku w powiecie pułtuskim, Pułtusk 1990; J. Cygan, W. K. Cygan, Rok 1920 na Ziemi Mińskiej, Mińsk Mazowiecki 2010; M. Dauksza, Siedlczanie wobec bolszewickiej inwazji 1920 r., „Prace Archiwalno-Konserwatorskie na terenie województwa siedleckiego” 1997, z. 10; J. Dębiński, Inwazja bolszewicka na Ziemi Dobrzyńskiej i Kujawach wschodnich, "Grot. Zeszyty Historyczne” 2005, nr 24; A. Gontarek, Żydzi Mińska Mazowieckiego w latach 1918-1939, Lublin 2015; J. Kuligowski, Mińsk Mazowiecki i okolice podczas Bitwy Warszawskiej 1920 r., „Rocznik Mińsko-Mazowiecki” 2000, nr 6; idem, Pod okupacją sowiecką: /Mińsk w sierpniu 1920 r./, „Rocznik Mińsko-Mazowiecki” 1996, nr 3; P. Bednarczyk, S. Piątkowski, „Twierdza nam będzie każdy próg...”. Społeczeństwo Ziemi Radomskiej w okresie wojny polsko-bolszewickiej lat 1919-1920, Radom 2015; S. Bizan, Powiat i miasto Brodnica w walkach o niepodległość 1914-1920 rok, Brodnica 1939; P. Borek, Postawa społeczeństwa południowego Podlasia wobec kontruderzenia znad Wieprza w sierpniu 1920 roku, „Radzyński Rocznik Humanistyczny" 2010, nr 8; idem, Działalność siedleckiego komitetu wojskowo-rewolucyjnego w sierpniu 1920 roku, „Komunizm: System-Ludzie-Dokumentacja” 2014, nr 3; Rok 1920 na Podlasiu. Materiały z sesji popularno-naukowej zorganizowanej 10 XI 1990 r.w Białej Podlaskiej, red. H. Mierzwiński, Biała Podlaska 1990; M. Drozdowski, Warszawa w obronie Rzeczypospolitej czerwiec-sierpień 1920, Warszawa 1993.

${ }^{3}$ Zob. P. Ejsmond, Przestępstwo dezercji. Rys prawno-historyczny, „Przegląd Morski” 1984, z. 7-8; R. Kasprzycki, Dezercje i unikanie stużby w WP w latach 1918-1939, „Dzieje Najnowsze” 2016, nr 3; P. Stawecki, Z badań nad dyscyplina, przestępczościa i moralnościa wojska Drugiej Rzeczypospolitej, Warszawa 2000; A. Smoliński, Morale i dyscyplina Wojsk Wielkopolskich 1918-1919, Toruń 2009; J. Suliński, Dezercje w okresie międzywojennym, „Wojsko i Wychowanie” 1997, nr 3; J. Zając, O podstawach karności wojskowej, Warszawa 
z prac biograficznych, studiów poświęconych praktyce sądów polowych i oficerskich sądów honorowych ${ }^{4}$. To jednak nie koniec drogi. W dalszym ciągu wiemy o tej wojnie znacznie mniej, niż powinniśmy wiedzieć, gdyż mamy za sobą pół wieku zwłoki w badaniach.

Niniejszy artykuł jest szkicem poświęconym mniej znanej problematyce postaw polskiego społeczeństwa wobec wykonania obowiązku wojskowego w czasie wojny z Rosją bolszewicką w latach 1919-1920. Zagadnienie jest o tyle istotne, że wymaga zdefiniowania występujących w toku wojny $\mathrm{z}$ bolszewikami zagrożeń dla funkcjonowania służby poboru i uzupełnień oraz przeciwdziałania zjawisku dezercji z wojska, zaś te godziły w zdolność bojową oddziałów frontowych Wojska Polskiego i moc obronną Rzeczypospolitej. Bazę źródłową niniejszego opracowania stanowią dokumenty wytworzone przez Naczelne Dowództwo WP (NDWP), dowództwa wojskowe, Żandarmerię Polową, sądy polowe, defensywę, organy władzy publicznej, doniesienia prasowe i publikowane dotąd wyniki badań. Niniejszy artykuł stanowi przyczynek do zbiorowego portretu polskiej armii, która obroniła młode państwo na progu niepodległości. Ograniczone ramy opracowania pozwalają tylko na powierzchowne ujęcie zagadnienia, które winno być przedmiotem oddzielnej monografii.

\section{Stosunek społeczeństwa polskiego i mniejszości narodowych do zjawiska dezercji i uchylania się od poboru w pierwszym roku wojny}

Wojsko Polskie było lustrzanym odbiciem narodowościowej mozaiki, z której po zaborach składała się odrodzona Rzeczypospolita. Żywioł polski stanowił nie więcej niż 70\% całego społeczeństwa. Dziesięć lat po omawianych wydarzeniach państwo polskie zamieszkiwało: ok. 20,6 mln Polaków, 5,1 mln Ukraińców, 3,1 mln Żydów, ok. 2 mln Białorusinów, ok. 784 tys. Niemców (tylko na Górnym Śląsku ok. 520 tys.), ok. 200 tys. Litwinów, ok. 140 tys. Rosjan i co najmniej 90 tys. Romów, Czechów, Słowaków, Węgrów, Karaimów i Tatarów ${ }^{5}$. W czasie wojny z Rosją bolszewicką w latach 1919-1921

1922; K. Chodkiewicz, W. Stępek, Stużba wywiadowcza i ochrona przeciwszpiegowska, Poznań 1925; G. Ratajczyk, Żandarmeria Wojska Polskiego II Rzeczypospolitej, Toruń 2004.

${ }^{4}$ J. Krzemieński, Wymiar sprawiedliwości w Wojsku Polskim, „Wojskowy Przegląd Prawniczy” 1928, nr 8-10; T. Rybicki, Sadownictwo polowe w latach wojny 1919-1921, „Wojskowy Przegląd Prawniczy" 1928, nr 8-10; L. Kania, Wyroki bez apelacji. Sądy polowe w Wojsku Polskim w czasie wojny z Rosją Sowiecką 1919-1921, Zielona Góra 2019; G. Kulka, Sąd honorowy dla generatów w Wojsku Polskim w latach 1918-1947, Oświęcim 2017.

${ }^{5}$ Zob. M. Iwanicki, Ukraincy, Białorusini, Litwini i Niemcy w Polsce w latach 1918-1990, Siedlce 1991. We wrześniu 1921 r. na podstawie ustawy z 21 X 1919 r. o organizacji statystyki administracyjnej (Dziennik Ustaw Rzeczypospolitej Polskiej/dalej: Dz. U. RP/ 1919, nr 85, poz. 464) przeprowadzono spis ludności, nie objął jedynie terytorium Litwy Środkowej 
proporcje musiały być podobne. Eufemistycznie rzecz ujmując, nie wszyscy mieszkańcy odrodzonej Rzeczypospolitej chcieli się bić za polskie państwo. Czynnik etniczny miał zatem istotne znaczenie. Dezercje z wojska pojawiły się niemal od pierwszych dni formowania sił zbrojnych. Wojsko Polskie jako armia narodowa powstało w końcu października 1918 r., a pierwsze regularne oddziały wojskowe były tworzone na zasadzie werbunku i zaciągu ochotniczego. Jednak i w formacjach ochotniczych zdarzały się samowolne oddalenia i dezercje, gdyż żołnierz ochotniczy uważał, że jeśli sam przyszedł do wojska, to sam może również odejść. Taka postawa cechowała wszystkie formacje, które biły się w powstaniu wielkopolskim, trzech górnośląskich zrywach powstańczych i w bojach z Ukraińcami o Lwów ${ }^{6}$.

W listopadzie 1918 r. wszystkie formacje WP liczyły nie więcej niż 30 tys. oficerów i żołnierzy, zaś dalszy liczebny rozwój sił zbrojnych bazował na przymusowym poborze. W styczniu 1919 r. zmobilizowanych było już 110 tys. oficerów i żołnierzy, lecz nie więcej niż 23 tys. walczyło w polu? Ale mimo legendy czynu legionowego i ziszczenia marzeń kilku pokoleń Polaków o posiadaniu własnego państwa w społeczeństwie polskim dominowały tendencje pacyfistyczne. W lutym 1919 r. kierownictwo państwa zmuszone było zdecydować się na bardzo źle przyjęty, ale konieczny krok ogólnokrajowego poboru roczników 1896-1900. Tym samym zakończył się etap spontanicznego tworzenia sił zbrojnych bazujący na zaciągu ochotniczym. Do sformowania armii z powszechnego poboru - a tylko taka mogła odeprzeć odwiecznego wroga ze wschodu - potrzebny był dobrze funkcjonujący system doboru kadr. Służba Poboru i Uzupełnień powstała już w listopadzie 1918 r. w strukturze Departamentu I Mobilizacyjno-Organizacyjnego Ministerstwa Spraw Wojskowych (MSWojsk.), a na terenach kontrolowanych przez władze Rzeczypospolitej rozwinięto wkrótce sieć urzędów wojskowych odpowiedzialnych za przymusowy pobór i zaciąg ochotniczy do Wojska Polskiego ${ }^{8}$. W kwietniu 1919 r. pod bronią było 200 tys. oficerów i żołnierzy, zaś w drugiej połowie 1919 r. wcielono dalszych 300 tys. żołnierzy99. Jakościowo i ilościowo Wojsko Polskie wzmocniło

i Górnego Śląska, który przypadł Rzeczypospolitej. Wedle spisu tylko 69\% ludności zadeklarowało narodowość polską. Zob. też M. Leczyk, Oblicze społeczno-polityczne II Rzeczypospolitej, Warszawa 1988, s. 70-71.

${ }^{6}$ L. Kania, W cieniu Orlat lwowskich. Polskie sądy wojskowe, kontrwywiad i służby policyjne w bitwie o Lwów 1918-1919, Zielona Góra 2009, s. 310.

${ }^{7}$ M. Szczepkowski, Zarys organizacji Wojska Polskiego na przełomie lat 1918 i 1919, „Wojskowy Przegląd Historyczny” 1990, nr 3/4 (133/134), s. 16.

${ }^{8}$ B. Woszczyński, Ministerstwo Spraw Wojskowych 1918-1921. Zarys Organizacji i działalności, Warszawa 1971, s. 289-290.

${ }^{9}$ M. Kukiel, Dzieje Polski porozbiorowe 1795-1921, Paryż 1983, s. 630; P. Stawecki, Wskrzeszenie Wojska Polskiego na przełomie lat 1918 i 1919, „Studia i Materiały do Historii Wojskowości” 1987, s. 231. 
się w drugiej połowie 1919 r. po scaleniu z Armią gen. Józefa Hallera i Armią Wielkopolską. W końcu 1919 r. Wojsko Polskie liczyło już 600 tys. oficerów i żołnierzy i miało się nadal w szybkim tempie rozwijać ${ }^{10}$.

Na drodze do liczebnego wzrostu polskich sił zbrojnych stanęły przeszkody natury prawnej. W wieloetnicznym społeczeństwie Rzeczypospolitej problemem stali się apatrydzi, tj. mieszkańcy nieposiadający żadnego obywatelstwa. Większość z nich nie chciała służyć w Wojsku Polskim. Dotyczyło to kilkuset tysięcy mężczyzn w wieku poborowym wywodzących się z mniejszości narodowych. Kwestie natury konstytucyjnej i niejasny status członków mniejszości narodowych wyjaśniły dopiero postanowienia traktatów pokojowych kończących I wojnę światową. Sytuację prawną poborowych (tzw. popisowych) innych narodowości niż polska zamieszkujących ziemie włączone w skład Rzeczypospolitej komplikowały postanowienia Traktatu między Głównymi Mocarstwami Sprzymierzonemi i Stowarzyszonemi a Polska zawartego w Wersalu w dniu 28 czerwca 1919 r. ${ }^{11}$ i postanowienia Traktatu między Głównemi Mocarstwami Sprzymierzonemi i Stowarzyszonemi a Austria zawartego w Saint-Germain-en-Laye w dniu 10 września 1919 r. $^{12} \mathrm{Na}$ mocy tych traktatów, które tworzyły przez kolejnych 20 lat fundament prawa międzynarodowego w Europie, mieszkańcom Rzeczypospolitej innych narodowości niż polska przysługiwało prawo opcji wyboru obywatelstwa w połączeniu z prawem zmiany miejsca zamieszkania. Popisowi pochodzenia niemieckiego mogli zgodnie z prawem uchylać się od obowiązkowej służby w Wojsku Polskim, korzystając z tzw. „prawa optanta”, tj. wyboru opcji obywatelstwa. Ukraińców, Niemców i Rosjan w czasie wojny nie powoływano do wojska, zaś Żydów zaczęto wzywać do wykonania obowiązku wojskowego i kierować na front dopiero od jesieni 1919 r. po wyjaśnieniu kwestii ich obywatelstwa w świetle norm traktatowych.

Poważną barierą realizacji powszechnego poboru był fatalny stan zdrowia milionów mężczyzn w wieku poborowym. Niestety, tylko część rekrutów spełniała kryteria zdrowotne. Im dalej na wschód, tym było gorzej. Po kilku latach wojny europejskiej młodzi ludzie byli niedożywieni i schorowani. Na dodatek szalały pandemie takich chorób zakaźnych jak grypa, tyfus i czerwonka, które w całej Europie zabiły kilkadziesiąt milionów ludzi. W Galicji młodzież chłopska pod względem zdrowotnym była najbardziej zabiedzona spośród wszystkich dzielnic. Dość przypomnieć, że jeszcze w austro-węgierskiej monarchii w 1889 r. minimalny wzrost popisowych zmniejszono ze $155 \mathrm{~cm}$ do $153 \mathrm{~cm}$, aby zwiększyć populację młodych mężczyzn zdolnych do służby wojskowej ${ }^{13}$.

\footnotetext{
${ }^{10}$ M. Szczepkowski, Zarys organizacji..., s. 21.

${ }^{11}$ Dz.U. RP 1919, nr 110, poz. 728.

${ }^{12}$ D. Malec, Obywatelstwo państwa polskiego w świetle orzecznictwa Najwyższego Trybunału Administracyjnego 1922-1939, „Miscellanea Historico-Iuridica” 2015, t. XIV, z. 2, s. 75.

${ }^{13}$ M. Baczkowski, Pod czarno-żółtymi sztandarami. Galicja i jej mieszkańcy wobec austro-węgierskich struktur militarnych 1868-1914, Kraków 2003, s. 131.
} 
Odsetek mężczyzn uznanych przez komisje lekarskie za niezdolnych do służby wojskowej oscylował w Galicji Wschodniej miedzy 47,3 a 71,9\%14. Jesienią 1918 r. wcale nie było lepiej. Co lepsi i zdrowsi mężczyźni zostali wcieleni do armii zaborczych i zmarnowani na frontach Wielkiej Wojny. Dlatego wielu poborowych uzyskało na przełomie 1918 i 1919 r. odroczenie od czynnej służby wojskowej na okres od 3 do 6 miesięcy.

Struktura społeczna powołanej pod broń masy ludzi w pierwszych miesiącach wojny wykazywała przewagę inteligencji i robotników nad stanem włościańskim. W pierwszej fazie wojny problemem był bowiem bojkot poboru do wojska przez ludność wiejską. Wieś mimo natrętnie uprawianej legendy o tych, którzy zawsze „żywią i bronią”, z dużą niechęcią traktowała obowiązek wojskowy. Nawet w szczytowym okresie zmagań z Armią Czerwoną chłopi w Sandomierskiem dopytywali, czy zwyciężają „Polacy”, czy górą są „nasi bolszewicy”, którzy byli uosabiani z Rosją carów ${ }^{15}$. Janusz Odziemkowski, znawca polskiej wojskowości, przytacza fragment raportu płk. Michała Tokarzewskiego z 17 marca 1919 r., z którego przebija rozpacz na jakość nowych rekrutów: „[...] z Białej Podlaskiej przyjechał transport do Ostrowi złożony z 500 rekrutów, 150 po drodze uciekło, a reszta tak zdemoralizowana, że dowództwo dywizji odsyła ich z powrotem"16. W pomnikowej pracy tego autora poznajemy zasadniczą różnicę między materiałem żołnierskim stanowiącym trzon starych pułków, a rekrutami z przymusowego poboru. Wśród nowo wcielonych żołnierzy z terenów wiejskich przebijał opór przed pójściem na front. Tylko z obszaru OGen. Kielce zbiegło do Rzeszy Niemieckiej kilkuset mężczyzn ${ }^{17}$. Z Pomorza i północnego Mazowsza masowo uciekali do Gdańska młodzi Żydzi i Niemcy, którzy nie uregulowali swego statusu ${ }^{18}$. Poziom niechęci wobec służby w Wojsku Polskim zaskoczył kierownictwo państwa. Wszak pobór do armii rosyjskiej przebiegał bez przeszkód, a wstrząsające realia życia w porewolucyjnej Rosji i okrucieństwa bolszewików były powszechnie znane.

Biegunowo odległym zjawiskiem wobec uchylania się od poboru i dezercji z oddziałów frontowych były ucieczki żołnierzy z oddziałów zapasowych i jednostek szkoleniowych na front. Sprawy te nie trafiły na wokandę sądów wojskowych, więc niewiele o nich wiemy. Żołnierze rwący się do walki nie mieli serca do szkolenia na tyłach i w okresie rekruckim uciekali na front. Tam takich „zbiegów” przyjmowano z entuzjazmem i ukrywano ich obecność,

\footnotetext{
${ }^{14}$ P. Bednarczyk, S. Piątkowski, „Twierdzq nam będzie każdy próg...”, s. 76.

${ }^{15}$ S. Grabski, Pamiętniki, t. II, Warszawa 1989, s. 155.

${ }^{16}$ J. Odziemkowski, Piechota polska..., s. 62.

${ }^{17}$ Ibidem.

${ }^{18}$ J. Szczepański, Społeczeństwo Polski..., s. 46.
} 
gdyż byli dobrym materiałem żołnierskim. Niektórzy rejestrowali się pod fałszywymi nazwiskami, byle tylko dostać karabin do ręki i bić wroga. Potem dochodziło do kuriozalnych sytuacji, gdy uciekinierzy na front figurowali w listach gończych jako dezerterzy z macierzystych jednostek, a w tym czasie walczyli, ginęli i odnosili rany. Dodatkowym problemem były ucieczki z domów na front małoletnich chłopców. Takie przypadki odnotowano już w czasie obrony Lwowa w listopadzie $1918 \mathrm{r}$. Młodzi chłopcy z całego kraju urzeczeni romantycznymi doniesieniami o wyczynach „Orląt” lwowskich uciekali z domów i przedzierali się do oddziałów. W prasie spotykamy mnóstwo ogłoszeń zrozpaczonych rodziców, którzy poszukiwali swoich synów w linii bojowej. W latach woj-

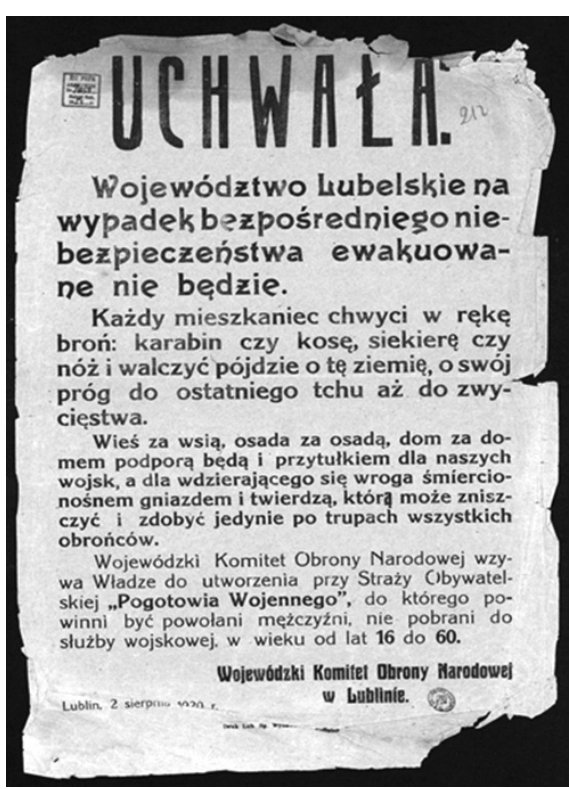

Plakat propagandowy adresowany do ludności chłopskiej

Źródło: Archiwum Akt Nowych w Warszawie, Akta instytucji wojskowych 1916-1939, sygn. 2/1401/0. ny z Rosją bolszewicką takie przypad-

ki też miały miejsce. Tyle że Wojsko Polskie było armią regularną i ochotnik musiał posiadać dowód tożsamości, przedstawić pisemną zgodę rodziców i potwierdzić aktem urodzenia ukończenie 17. roku życia ${ }^{19}$. Zachowały się dokumenty wytworzone przez oficerów służby poborowej, w których odmawiali małoletnim ochotnikom przyjęcia do wojska ze względu na brak zezwolenia rodziców lub sfałszowanie ich podpisów ${ }^{20}$. Szkodliwy zwyczaj przyjmowania zbiegów $\mathrm{z}$ innych jednostek przeciął rozkaz ministra spraw wojskowych z 28 listopada 1919 r., który pod groźbą kar sądowych zabronił tego rodzaju praktyk na przyszłośćc1. Od tej pory każdy żołnierz dezerterujący

${ }_{19}$ Zob. pisemne zgody rodziców małoletnich i młodocianych ochotników do Armii Ochotniczej [w:] Rok 1920 w obrazie i dokumencie. Wojna $z$ bolszewikami w zbiorach archiwów polskich, red. M. Olczak, J. Stryjek, Warszawa 2020, s. 211.

${ }^{20}$ Archiwum Akt Nowych w Warszawie (dalej: AAN), Związek Harcerstwa Polskiego (dalej: ZHP), Osobowy Referat Odznaczeń, sygn. 1872, b.m., b.d., k. 113 i n.; Główna Kwatera Męska. Referat wojskowy, sygn. 1665, b.m., b.d., k. 303-306.

${ }^{21}$ Centralne Archiwum Wojskowe Wojskowego Biura Historycznego (dalej: CAW-WBH), Rozkazy Poufne Dowództwa Okręgu Korpusu Grodno za okres 20.01.1920 r.-13.07.1920 r., 
na front, abstrahując od szlachetnych pobudek tego czynu, musiał być dostawiony pod eskortą na powrót do macierzystej jednostki.

W czasie tej wojny zdarzały się i takie sytuacje, których prawodawca nie zdołał przewidzieć. W dokumentach wojskowych znajdujemy dowody na dezercje żołnierzy z oddziałów liniowych do oddziałów na zapleczu frontu. Celowali w tym zwłaszcza żołnierze pochodzenia żydowskiego, którzy częstokroć przewyższali inteligencją i sprytem żołnierzy innych narodowości. Zjawisko dezercji „, zojska do wojska” było o tyle ciekawe, że w postępowaniu przed sądem wojskowym trudno było takim zbiegom wykazać „trwałe uchylanie się od służby wojskowej", co znów było warunkiem sine qua non uznania takiego czynu za przestępstwo. Do sądowych rozliczeń z takimi zbiegami doszło dopiero w ostatniej fazie wojny i tuż po jej zakończeniu. Dla przykładu, Sąd Wojskowy Dowództwa Okręgu Generalnego (DOGen.) w Lublinie wyrokiem z 13 października 1921 r. skazał na karę 2 lat więzienia podoficera $\mathrm{z}$ kompanii sztabowej 23 pp, który bezprawnie przyjął do swojej kompanii trzech dezerterów $\mathrm{z}$ innych jednostek w zamian za łapówki. Dezerterzy: szer. Josek Ajzenkajt z 22 pp, szer. Mordka Bekerman z 8 pp i szer. Rafał Chager z 44 pp zostali po wojnie skazani na kary po 1,5 roku ciężkiego więzienia ${ }^{22}$. Jak widać, nie były to kary dolegliwe jeśli zważyć, że dzięki fortelowi i łapówkom żołnierze uniknęli służby frontowej.

$\mathrm{Z}$ analizy raportów sądów polowych i wydanych wyroków wynika, że najmniej dezercji było $w$ formacjach legionowych, wielkopolskich, dywizjach litewsko-białoruskich i tworzonych na bazie przybyłych z Francji oddziałów Armii gen. Hallera ${ }^{23}$. Nieprzypadkowo też morale było w tych dywizjach wysokie pomimo dotkliwych strat i braku elementarnego wyposażenia osobistego, nie wyłączając braku butów, bielizny i mundurów ${ }^{24}$. Naturalnie, w czasie tej wojny dały o sobie znać partykularyzmy dzielnicowe i uprzedzenia, które były wynikiem rozdzielenia Polaków na ponad sto lat przez zaborców. Wielkopolanie początkowo nie widzieli racjonalnego powodu wojny z bolszewikami, zaś Górnoślązacy ze 167 pp (dawnego 1 Pułku Strzelców Bytomskich) w czasie walk nad Autą i Berezyną głośno sarkali, że walczą tak daleko od ziemi rodzinnej. Paradoksalnie najwięcej dezercji w czasie wojny odnotowano w pułkach zapasowych i formacjach tyłowych (70-75\%). Dlatego najwięcej wyroków sądów cywilnych i wojskowych przeciwko dezerterom

sygn. DOK III/3, Rozkaz MSWojsk. Dep. I. Nr 2594/Mob. z 28.11.1919 r. i Rozkaz Poufny Nr 2 DOGen. Grodno z 9.02.1920 r.

${ }^{22}$ CAW-WBH, Oddział VI Prawny Sztabu MSWojsk., sygn. I. 300.12.30, Wyrok Sądu Wojskowego DOGen. Lublin z 4.06.1921 r., sygn. L. 1122/21, b.m., b.p. [przewodniczący: mjr Rudolf Quatter].

${ }^{23}$ L. Kania, Wyroki bez apelacji..., s. 134-203.

${ }^{24}$ J. Odziemkowski, Piechota polska..., s. 148. 
i osobom uchylającym się od poboru zapadło na zapleczu frontu w sądach polowych Dowództw Okręgów Etapów. Dowódcy frontów (armii) i związków taktycznych jako dysponenci sądów polowych i zarazem jako zwierzchnicy sądowo-karni decydowali się wyjątkowo na prewencyjne karanie śmiercią dezerterów dla odstraszenia naśladowców ${ }^{25}$. W polityce karnej dominowały surowe kary sądowe do kary śmierci włącznie, ale ich wykonanie zazwyczaj odraczano na czas powojenny. To dawało skazanym możliwość zrehabilitowania się na polu walki ${ }^{26}$.

\section{Walka $\mathrm{z}$ dezercją i uchylaniem się od służby wojskowej w drugim roku wojny}

W drugim roku zmagań wojennych z Rosją bolszewicką przestępstwa przeciwko obowiązkowi wojskowemu stały się istną plagą. Był to efekt liczebnego wzrostu sił zbrojnych i naturalnego lęku młodych rekrutów przed wejściem do walki. Wiosną 1920 r. aparat policyjny, Żandarmeria Wojskowa i służby garnizonowe na tyle okrzepły, że mogły przystąpić do szeroko zakrojonych działań przeciw popisowym uchylającym się od poboru i dezerterom. Impulsem do działania był słaby rezultat akcji poborowej roczników 1900-1901. W Kaliszu tylko w pierwszych trzech miesiącach 1920 r. Żandarmeria schwytała 550 dezerterów, w Białymstoku - $600^{27}$. Dezercje wzmogły się nie tylko na froncie. W marcu 1920 r. tylko na terenie DOGen. Łódź zdezerterowało 474 żołnierzy. Z rozkazu MSWojsk. zarządzono cykliczne obławy na dezerterów. Największe przeprowadzono w dniach 12-17 maja 1920 r. W Radomiu i na terenie powiatu radomskiego podczas jednodniowej obławy ujęto 464 osoby pod zarzutem uchylania się od poboru ${ }^{28}$. Na obszarze działania Powiatowej Komendy Uzupełnień Pułtusk schwytano 400 osób uchylających się od poboru i 21 dezerterów ${ }^{29}$. Na terenie DOGen. Kielce tylko w maju 1920 r. zatrzymano 2 tys. dezerterów i osób uchylających się od poboru ${ }^{30}$. W powiecie kozienickim w okresie od stycznia do lipca $1920 \mathrm{r}$. funkcjonariusze Policji Państwowej ujęli 753 mężczyzn uchylających się od poboru

${ }^{25}$ L. Kania, Instytucja zwierzchnika sądowo-karnego jako dysponenta sądu polowego $w$ Wojsku Polskim w latach wojen o granice Rzeczypospolitej 1918-1921, „Z Dziejów Prawa” 2020 , t. 12 , s. $435-458$.

${ }^{26}$ Zob. Idem, Organizacja i rys działalności sądów polowych Naczelnego Dowództwa WP $w$ przełomowym okresie wojny z Rosja sowiecką latem 1920 r., cz. 1, „Przegląd Historyczno-Wojskowy" (PHW) 2018, nr 3/4 (265/266), s. 45-85; cz. 2, PHW 2019, nr 1 (267), s. 75-118.

${ }^{27}$ Idem, Wyroki bez apelacji..., s. 290-291.

${ }^{28}$ W. Jarno, Okręg Generalny WP nr III Kielce 1918-1921, Łódź 2003, s. 163.

${ }^{29}$ Ibidem.

${ }^{30}$ J. Szczepański, Społeczeństwo Polski..., s. 104-105. 
do wojska i dezerterów ${ }^{31}$. W obławie przeprowadzonej w powiecie olkuskim w pierwszych dniach lipca 1920 r. ujęto tylko jednego dnia 54 dezerterów i 264 osoby uchylające się od poboru ${ }^{32}$. W powiecie iłżeckim mieszkańcy wsi byli szczególnie podatni na lewicową agitację. Propaganda bolszewicka początkowo trzymała ludzi z dala od wojska. Po części wynikało to $\mathrm{z}$ istoty bolszewickiego systemu, który po mistrzowsku opanował prowadzenie wojny psychologicznej ${ }^{33}$. W lutym $1920 \mathrm{r}$. w powiecie łomżyńskim stawiło się do wojska nie więcej niż $60 \%$ popisowych, zaś z powiatu ostrołęckiego ok. $40 \%{ }^{34}$. Najgorzej z poborem do wojska było w Białymstoku, gdzie w marcu 1920 r. na ogólną liczbę 1190 wręczonych kart powołania do koszar pułku zapasowego stawiło się tylko 172 młodych mężczyzn ${ }^{35}$.

Wpływało to demoralizująco na tych, którzy wykonali ciążący na nich obowiązek poborowy. Świadczą o tym bezspornie komunikaty wojskowe wszystkich DOGen. W raportach tych oficerowie skarżyli się, że przy zaciągu ochotniczym ,jeden czeka na drugiego" i lepiej natychmiast wprowadzić pobór pod przymusem ${ }^{36}$. W okresie przed apelem wystosowanym przez Wincentego Witosa pobór rekrutów ze środowiska wiejskiego zamarł ${ }^{37}$. Najgorszą pod tym względem sytuację odnotowano na Kielecczyźnie i na Mazowszu. $\mathrm{Na}$ terenie powiatu kozienickiego doszło do buntów całych wiosek, z których nikt nie chciał stawić się do poboru. Przywódcy chłopscy uzależniali poparcie dla wykonania obowiązku wojskowego, o ile wsi zostanie przyobiecana radykalna reforma rolna ${ }^{38}$. Dlatego nieprzypadkowo Józef Piłsudski, który dzierżył w tym czasie pełnię władzy wykonawczej i wojskowej, powierzył tekę Prezesa Rady Ministrów liderowi ruchu chłopskiego. Witos już swoim nazwiskiem miał ściągnąć do wojska rekrutów z terenów wiejskich i to uczynił. Mimo kolosalnych trudności akcja poborowa roczników 1895, 1900, 1901 i 1902 dała armii ok. 155 tys. nowych żołnierzy. Na koniec sierpnia 1920 r. Wojsko Polskie wraz z sojusznikami liczyło ponad milion oficerów

\footnotetext{
${ }^{31}$ P. Bednarczyk, S. Piątkowski, „Twierdzq nam będzie każdy próg...”, s. 96.

32 W. Jarno, Okręg Generalny WP nr III Kielce..., s. 148.

${ }^{33}$ S. Helma, Dezinformacja i wojna psychologiczna jako element polityki Zwiazku Sowieckiego i Federacji Rosyjskiej, „Zeszyty Naukowe Towarzystwa Doktorantów UJ. Nauki Społeczne” 2018, nr 3, s. 79-81.

${ }^{34}$ L. Kania, Wyroki bez apelacji..., s. 290-291.

${ }^{35}$ Ibidem.

${ }^{36}$ Komunikat informacyjny $n r$ 42/109/ z 31.07.1920 $r$. [w:] O niepodległa i granice, t. 2: Raporty $i$ komunikaty naczelnych władz wojskowych o sytuacji wewnętrznej Polski 1919-1920, oprac. i wybór M. Jabłonowski, P. Stawecki, T. Wawrzyński, Warszawa-Pułtusk 2000, s. 502.

${ }^{37}$ Komunikat informacyjny $\mathrm{nr}$ 41/108/ z 24.07.1920 r. [w:] ibidem, s. 499.

${ }^{38}$ Ibidem, s. 499-502.
} 
i żołnierzy, desygnując na front 297 batalionów piechoty, 171 szwadronów jazdy i 207 baterii artyleriii ${ }^{39}$.

Od pierwszych dni wojny dostrzeżono demonstracyjną niechęć ludności żydowskiej wobec służby w Wojsku Polskim. Z wyjątkiem spolonizowanej inteligencji i bogatego mieszczaństwa Żydzi w zdecydowanej masie wyczekiwali nadejścia Armii Czerwonej. Demonstracyjną wrogość wobec polskiej państwowości przejawiała mniejszość niemiecka, litewska i chłopstwo ukraińskie $^{40}$. W zasadzie najwięcej zrozumienia dla sprawy niepodległości Rzeczypospolitej mieli Białorusini i spolonizowani Żydzi. Cokolwiek do tego dodać, społeczeństwo polskie i jego armia miała na swoim terytorium kilka milionów ludzi, na których nie można było liczyć w godzinie próby. Zbolszewizowana młodzież żydowska nie utożsamiała się z młodym państwem polskim i tęsknie wyczekiwała nadejścia bolszewików. Tam, gdzie żołnierze-Żydzi stanowili znaczny odsetek składu osobowego oddziału, dowódcy mieli poważny kłopot na froncie. Najlepszym tego dowodem jest katastrofa 1 Brygady Piechoty Rezerwy w czerwcu 1920 r. nad Słuczą i Horyniem. W 106 pp znaczny procent składu osobowego stanowili żołnierze pochodzenia żydowskiego. Ci, niestety, nie przejawiali ochoty do walki. Przy pierwszej akcji bojowej pod Zwiahlem źle użyte $\mathrm{w}$ boju bataliony poszły $\mathrm{w}$ rozsypkę. $\mathrm{Z}$ bolszewicką konnicą walczyli głównie poznańscy oficerowie i elewi, dlatego straty bezpowrotne w kadrze dowódczej były olbrzymie. Wedle raportów dowództwa i materiałów przeprowadzonego $\mathrm{w}$ tej sprawie śledztwa Żydzi zbiegali do bolszewików, dezerterowali na tyły lub chowali się w okopach i porzucali broń ${ }^{41}$. Lepsze efekty uzyskiwano tam, gdzie żołnierzy żydowskiego pochodzenia starano się rozproszyć po oddziałach. Jak ustalił Odziemkowski, młodzi rekruci w celu uniknięcia służby na froncie wstrzykiwali sobie pod skórę naftę lub inne środki chemiczne, aby wywołać gorączkę lub symulować niebezpieczną chorobę $^{42}$. Latem radykalnie wzrosła liczba samopostrzeleń w lewą rękę lub pod obojczyk. To były znane od zamierzchłych czasów sposoby powodowania samouszkodzeń i samookaleczeń. Od połowy czerwca 1920 r. gwałtownie wzrosła liczba takich przypadków na froncie, co wywołało reakcję najwyższych władz wojskowych, o czym będzie jeszcze mowa.

\footnotetext{
${ }^{39}$ L. Wyszczelski, Wojsko Polskie..., s. 87.

${ }^{40}$ J. Szczepański, Wojna 1920 roku w powiecie pultuskim..., s. 13; A. Gontarek, Żydzi Mińska Mazowieckiego..., s. 422; S. Bizan, Powiat i miasto Brodnica..., s. 65 i n.; Raport polityczno-informacyjny ND WP o sytuacji na Suwalszczyźnie, Litwie i Okręgu Krakowskim z 17 marca 1920 r. [w:] O niepodległa i granice..., s. 122; Raport polityczno-informacyjny MSWojsk. o sytuacji w kraju z 9 lipca 1919 r. [w:] ibidem, s. 214.

${ }^{41}$ Zob. L. Kania, Klęska 1 Brygady Piechoty Rezerwy na Wolyniu w czerwcu 1920 r. w materiałach śledztwa prokuratorskiego, „Dzieje Najnowsze” 2019, nr 3, s. 29-49.
}

${ }^{42}$ J. Odziemkowski, Piechota polska..., s. 314. 
W drugiej połowie lipca 1920 r. nawet największy optymista nie wątpił, że Armia Czerwona dotrze do serca kraju. W krytycznym momencie wojny ogłoszono zaciąg do Armii Ochotniczej obywateli Rzeczypospolitej, na których dotąd nie ciążył obowiązek poborowy. W krytycznej sytuacji państwa przyjmowano wszystkich zdrowych mężczyzn w wieku od 17 do 42 lat, zaś oficerów do 50. roku życia. Premier Witos w dniu 30 lipca 1920 r. wydał odezwę do ludności wiejskiej, w której wezwał do poparcia rządu i wstępowania do Wojska Polskiego. Wezwał też chłopów do wydawania dezerterów władzom wojskowym ${ }^{43}$. Pobór roczników 1895 i 1902 wypadł, niestety, słabo. Ze środowiska wiejskiego dobiegały głosy o potrzebie wprowadzenia powszechnej mobilizacji, gdyż pobór i zaciąg ochotniczy nie przynoszą efektów ${ }^{44}$. Sytuację polepszyła masowa agitacja za wstępowaniem do wojska, którą Witos rozpoczął na łamach prasy ludowej ${ }^{45}$. W ciągu kilku dni wieś zasypały artykuły omawiające założenia reformy rolnej i przedstawiające ją jako bezsprzeczny sukces ludowców, który może zaprzepaścić bolszewickie zwycięstwo ${ }^{46}$. Z badań Odziemkowskiego wynika, że nie wszyscy rekruci z obszarów wiejskich nadawali się do służby wojskowej. Wielu było słabej kondycji, kiepskiego ducha i wypadało niekorzystnie na tle rekrutów $\mathrm{z}$ ośrodków miejskich ${ }^{47}$. Mimo to rekrut $\mathrm{z}$ terenów wiejskich nie odbiegał jakościowo od żołnierza bolszewickiego w polu i w służbie liniowej. Tymczasem w miastach i miasteczkach przed punktami werbunkowymi ustawiały się kolejki ochotników do wojska. W Częstochowie w połowie maja 1920 r. stu ozdrowieńców na własną prośbę skróciło leczenie szpitalne i zażądało odesłania na front. Ludność miasta $\mathrm{z}$ orkiestrą żegnała ich na dworcu, a żołnierze przed odjazdem na front skandowali patriotyczne hasła. Do połowy sierpnia $1920 \mathrm{r}$. w obliczu zagrożenia stolicy wcielono do wojska nie mniej niż 105 tys. ochotników $^{48}$. Tylko w okresie od 27 czerwca do 26 sierpnia 1920 r. w szeregach Wojska Polskiego znalazło się ok. 193 tys. nowych żołnierzy. Najlepsze wyniki poboru osiągnięto w Wielkopolsce - 26995 rekrutów. Na obszarze DOGen. Poznań nie stwierdzono większych problemów z dezercją. Wielkopolanie mieli wysokie poczucie obowiązku wobec państwa. Dobre wyniki poboru odnotowało także DOGen. Łódź. Tylko w sierpniu 1920 r. do wojska zgłosiło się tam 23770 rekrutów. Dla porównania, na terenie DOGen. Warszawa - 22334 ochotników.

${ }^{43}$ W. Witos, Wybór pism, red. J. Borkowski, Warszawa 1989, s. 107.

${ }^{44}$ Komunikat informacyjny nr 42 z 31.07.1920 r. [w:] O niepodległa i granice..., s. 502.

${ }^{45}$ J. Szczepański, Społeczeństwo Polski..., s. 180.

${ }^{46}$ W. Oleksiewicz, Chłopi i ruch ludowy w obronie niepodległości Polski w 1920 roku, „Roczniki Dziejów Ruchu Ludowego” 1992, nr 27, s. 25.

${ }^{47}$ J. Odziemkowski, Wieś i armia w II Rzeczypospolitej, Wrocław-Warszawa-Kraków-Gdańsk-Łódź 1988, s. 17.

${ }^{48}$ L. Kania, Wyroki bez apelacji..., s. 289-294. 
Warto pamiętać, że znaczne połacie Mazowsza, Podlasia i Lubelszczyzny zostały stracone dla poboru ze względu na ich zajęcie przez nieprzyjaciela ${ }^{49}$.

Szczególnie cennym materiałem żołnierskim okazali się harcerze. Tylko w okresie od 17 lipca do 17 sierpnia 1920 r. w ramach zaciągu ochotniczego przyjęto do Wojska Polskiego ok. 20 tys. harcerzy, nie licząc młodzieży harcerskiej z Chorągwi Lwowskiej, Krakowskiej, Wielkopolskiej i drużyn galicyjskich $^{50}$. Co najmniej 5-6 tys. najstarszych harcerzy trafiło na front, a pozostali ze względu na małoletniość zostali przyjęci do służby pomocniczej. Co najmniej 3 tys. harcerzy weszło w skład pięciu pułków piechoty, tj. 201 pp, 205 pp, 232 pp, 236 pp i 21 pp p $^{51}$ Harcerze tworzyli też całe pododdziały, np. I Wileński Batalion Harcerski w składzie 1 Armii WP. Znaleźli się także w składzie kilku pułków piechoty i artylerii, tj.: 6 pp, 14 pp, 32 pp, 28 pp, Brygady Syberyjskiej, Oddziału Jazdy mjr. Feliksa Jaworskiego i kilku pułków artylerii ${ }^{52}$. Harcerze, choć przyjęci przez weteranów z rezerwą, to wnieśli w szeregi armii niezachwianą wiarę w zwycięstwo. Obok harcerzy do pułków ochotniczych zaciągnęli się mężczyźni w dojrzałym wieku, w tym znani politycy, adwokaci warszawscy, architekci, aktorzy, nauczyciele akademiccy, żeby wymienić Eugeniusza Śmiarowskiego, Stefana Korbońskiego, Świętosława Baudouin-Courtenaya, Maksymiliana Hartglasa, Mariana Rentgena, Jerzego Langroda, Jędrzeja Giertycha, Stanisława Thugutta, Stanisława Patka. Do legendy przeszła waleczność harcerzy w bojach nad Wkrą i pod Ossowem. Archiwum Związku Harcerstwa Polskiego zawiera kilkaset nazwisk harcerzy, którzy polegli śmiercią bohatera latem 1920 r. Przykładowo w jednym $\mathrm{z}$ raportów znajduje się opis śmierci nieznanego z nazwiska harcerza, który bronił do śmierci reduty pod Ostrowią Mazowiecką. Po wyczerpaniu amunicji dostał się w ręce Kozaków, którzy żądali od niego wypowiedzenia słów: „Precz z Polską!”. Dzielny harcerz nie złamał się mimo kaleczenia szablami. Wykrwawił się na śmierć, zawodząc uporem oprawców ${ }^{53}$. Do harcerzy i ochotników dołączali maturzyści i studenci. Wobec tych ostatnich władze wojskowe zastosowały dyplomatyczną presję. Według obowiązujących do pierwszych dni lipca 1920 r. przepisów maturzyści z lat 1919-1920 i studenci byli konsekwentnie odraczani od wcielenia do wojska. Ale kiedy młodemu państwu zagroziło unicestwienie, dalsze oszczędzanie kwiatu polskiej

${ }^{49}$ J. Szczepański, Społeczeństwo Polski..., s. 284; M. Szczepkowski, Warszawski Okręg Generalny 1918-1921, „Rocznik Mazowiecki” 1984, z. 3, s. 248.

${ }^{50}$ AAN, ZHP, Główna Kwatera Męska - Oddział Odznaczeniowy, sygn. 1665, Wykaz harcerzy w jednostkach Wojska Polskiego, b.m., b.d., k. 3-4.

${ }^{51}$ Ibidem.

${ }^{52}$ Ibidem, k. 5.

${ }^{53}$ AAN, ZHP, Osobowy Referat Odznaczeń, sygn. 1871, Raport o poległych z dnia $25 \mathrm{~V}$ 1935 r., b.m., k. 12. 


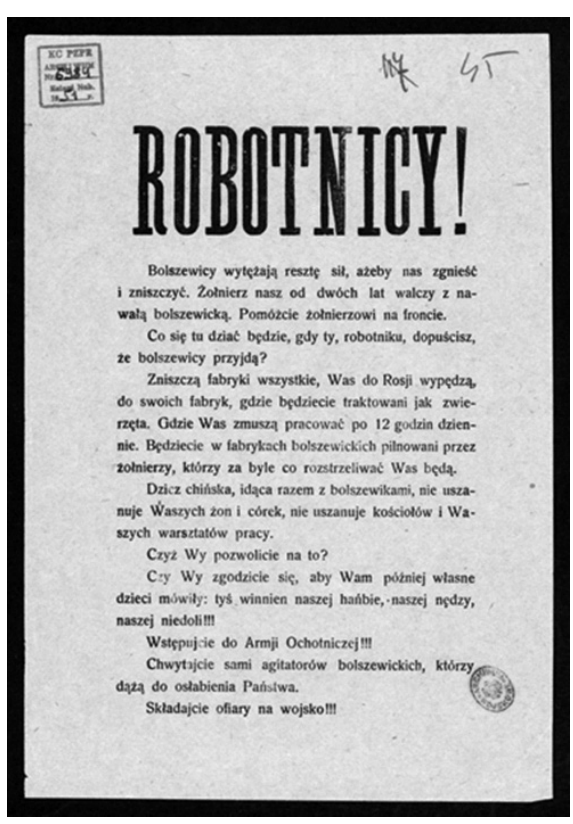

Odezwa propagandowa adresowana do robotników w $1920 \mathrm{r}$.

Źródło: AAN, Akta instytucji wojskowych 1918-1939, sygn. 2/1401/0 młodzieży nie miało sensu. W dniu 6 lipca 1920 r. gen. Kazimierz Sosnkowski, wiceminister spraw wojskowych, wydał specjalny rozkaz, w którym pozostawił studentom i maturzystom możliwość ochotniczego wstąpienia do Wojska Polskiego i zakreślił im na to termin do 15 sierpnia $1920 \mathrm{r}$. Po tej dacie maturzyści i studenci mieli być wcielani do wojska na zasadzie obowiązkowego poboru ${ }^{54}$.

Z każdym miesiącem służby policyjne i wojskowe odpowiedzialne za wyłapywanie osób uchylających się od poboru i dezerterów okazywały się bardziej skuteczne. Prasa codzienna ujawniała machinacje poborowe. „Kurier Poranny” w numerze datowanym na 16 września 1920 r. zamieścił artykuł o aresztowaniu przedsiębiorczej grupy warszawiaków, którzy wyreklamowali z wojska stu popisowych, załatwiając im za łapówki fikcyjne zaświadczenia, że są niezbędni w fabryce butów dla wojska ${ }^{55}$. Doniesienia o okrucieństwie bolszewików i wstrząsające relacje uciekinierów z Rosji w znacznym stopniu zmieniły podejście ludności wiejskiej do armii. Po sukcesach ofensywy sierpniowej zmienił się też stosunek opinii publicznej do dezerterów. Coraz częściej na obszarach wiejskich osobom uchylającym się od poboru i dezerterom odmawiano schronienia lub wydawano zbiegów Policji Państwowej i Żandarmerii Wojskowej ${ }^{56}$. Na Podlasiu patrole Związku Obrońców Ojczyzny z pomocą ludności wiejskiej wyłapywały dezerterów i odstawiały ich do komend wojkkowych ${ }^{57}$. Po wsiach krążyły grupy agitacyjne i lotne drużyny werbunkowe ${ }^{58}$. Pozytywna, patriotyczna przemiana mentalna ludności wiejskiej objawiła się dopiero w krytycznym

${ }^{54}$ CAW-WBH, Szefostwo Sądownictwa Polowego NDWP, sygn. I. 301.21.19, Rozkaz wiceministra S[praw] W[ojskowych] z 6 V 1920 r. Nr 34242.4471/20/I, b.m., b.p.

55 „Kurier Poranny”, 16 IX 1920, nr 254.

${ }^{56}$ Komunikat Informacyjny (sprawy wojskowe) nr 46 (113) z Okręgów Generalnych: Krakowa, Lublina i Łodzi [w:] O niepodległa i granice..., s. 526-537.

${ }^{57}$ J. Szczepański, Wojna 1920 na Mazowszu i Podlasiu, Pułtusk-Warszawa 1995, s. 336.

${ }^{58}$ P. Bednarczyk, S. Piątkowski, „Twierdzą nam będzie każdy próg...”, s. 94-95. 
momencie wojny, a warto wiedzieć, że większość składu osobowego wielkich jednostek stanowili rekruci z obszarów wiejskich ${ }^{59}$.

Powtarzające się przypadki współdziałania żołnierzy Armii Czerwonej z całymi oddziałami złożonymi z ochotników żydowskich i zjawisko masowej dezercji Żydów z oddziałów Wojska Polskiego zmusiły NDWP i kierownictwo sił zbrojnych do działania. Oficerowie i żołnierze WP żądali usunięcia z szeregów żołnierzy żydowskiego pochodzenia, na których nie mogli liczyć. Działacze żydowskiej partii socjalistycznej „Bund” w momencie zagrożenia stolicy wystąpili otwarcie przeciw Rzeczypospolitej. „Bundowcy” na posiedzeniu Rady Miejskiej m.st. Warszawy w końcu lipca 1920 r. jawnie opowiedzieli się po stronie Rosji bolszewickiej i sprzeciwili się akcji werbunkowej do Wojska Polskiego. W konsekwencji polski aparat bezpieczeństwa dokonał w tym środowisku aresztowań. Atmosfera wokół żołnierzy pochodzenia żydowskiego pogarszała się z każdym tygodniem wojny. Napływające z zaplecza frontu informacje o wiarołomstwie części żołnierzy-Żydów, o atakach ochotniczych formacji żydowskich na polskie oddziały i protesty oficerów skłoniły NDWP do podjęcia radykalnych kroków. Naczelny Wódz wydał rozkaz, aby oddziały frontowe nie miały w swym składzie więcej niż 10\% żołnierzy żydowskiego pochodzenia. Większy odsetek Żydów w oddziałach frontowych w opinii Naczelnego Wodza zmniejszał wartość bojową oddziałów frontowych ${ }^{60}$. Wykonując rozkaz Naczelnego Wodza w przedmiocie nowej polityki narodowościowej w Wojsku Polskim, gen. Sosnkowski w krytycznym momencie wojny nakazał wycofanie części żołnierzy-Żydów z linii bojowej i zgromadzenie ich w obozie wojskowym w Jabłonnie. Nie wszędzie zresztą ten rozkaz można było wykonać. Prewencyjnie usunięto też wszystkich Rosjan z Warszawy, których na krótko internowano. Jednocześnie minister spraw wewnętrznych rozwiązał „Bund” i zamknął jego siedziby.

W okresie od 16 sierpnia do 10 września 1920 r. przez obóz w Jabłonnie przewinęło się ok. 4-5 tys. żołnierzy pochodzenia żydowskiego, których wespół z saperami i ludnością cywilną wykorzystano do kopania okopów i zapór ziemnych pod Zegrzem i Wołominem. Niektórzy badacze (Szymon Rudnicki, Jolanta Załęczny) szacują ich liczbę nawet na kilkanaście tysięcy ${ }^{61}$. Liczba ta

${ }^{59}$ Z. Jagiełło, Piechota Wojska Polskiego 1918-1939, Warszawa 2005, s. 140.

${ }^{60}$ AAN, Akta Jana Kucharzewskiego, sygn. 2/2973/0, Pismo poufne Biura Propagandy Zagranicznej Prezydium Rady Ministrów z 30 IX 1920 r., nr L. 840/20 pn. „Sprawa obozu w Jabłonnej”, b.m., k. 1.

${ }^{61} \mathrm{O}$ rzekomych aresztowaniach żołnierzy-Żydów i co najmniej 10 tys. Żydów uwięzionych w Jabłonnie pod naciskiem „kół nacjonalistycznych" oprócz badaczy żydowskich pisali w ostatnich latach też polscy badacze, zob. prace Szymona Rudnickiego i Jolanty Załęczny: S. Rudnicki Żydzi w parlamencie II Rzeczypospolitej, Warszawa 2004, s. 50; J. Załęczny, Wydarzenia wojny polsko-bolszewickiej 1920 roku na terenie ówczesnego powiatu warszawskiego, „Niepodległość i Pamięć” 2010, nr 2 (32), s. 27-28. 


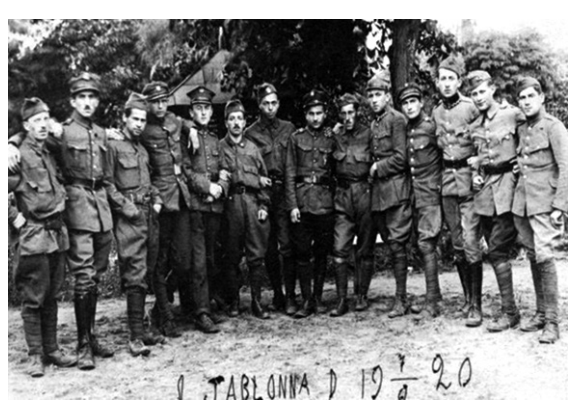

Żołnierze żydowskiego pochodzenia internowani w Jabłonnie w sierpniu $1920 \mathrm{r}$.

Źródło: domena publiczna

budzi wątpliwości. Fotografie i relacje żołnierzy-Żydów z pobytu w Jabłonnie nie budzą żadnych skojarzeń $\mathrm{z}$ warunkami o charakterze więziennym lub realiami obozu koncentracyjnego. Z niezrozumiałych powodów podnoszą to niektórzy badacze. W obozie wojskowym w Jabłonnie znalazło się na krótko wielu studentów, nauczycieli akademickich, ludzi świata nauki i literatów. Wydzielono dla nich kilka baraków. Obiekt stanowił polowe koszary dla batalionu zapasowego i nie miał nawet szczelnego ogrodzenia. W obronie rzekomo prześladowanych Żydów złożyli protest polscy intelektualiści, zamieszczając list otwarty w prasie stołecznej ${ }^{62}$. Pojawiły się oszczercze artykuły w prasie niemieckiej i amerykańskiej kontrolowanej przez żydowski kapitał, zaś gen. Maxime Weygand na łamach „Rzeczpospolitej” i „Journal de Pologne” pośpiesznie wyjaśnił, że „nie ma z obozem w Jabłonnie nic wspólnego". Nikt z żołnierzy-Żydów nie usłyszał zarzutu przestępstwa dezercji, usiłowania dezercji lub odmowy wykonania rozkazu. Żaden nie został też aresztowany. Krótki pobyt w Jabłonnie dotknął głównie nowo wcielonych rekrutów. Można zatem mówić o niewielkiej grupie żołnierzy WP żydowskiego pochodzenia wycofanych rozkazem NDWP na przełomie sierpnia i września 1920 r. z linii bojowej. Nikt ze zgromadzonych w Jabłonnie żołnierzy-Żydów nie stracił w tym czasie życia i nie odniósł obrażeń. W dzień rozwiązania obozu w Jabłonnej na podstawie rozkazu ministra spraw wojskowych $\mathrm{nr}$ L. 17680/Mob. z dnia 4 września 1920 r. urządzono ognisko pożegnalne $\mathrm{z}$ udziałem przedstawicieli najwyższych władz wojskowych, którym żołnierze urządzili owację ${ }^{63}$.

Szkoda, że badacze piszący o obozie w Jabłonnie nie chcą sięgnąć do przyczyn wszczęcia antyżydowskiej histerii, do zjawiska nielojalności proletariatu żydowskiego i masowych dezercji żołnierzy-Żydów z Wojska Polskiego. Pomija się też fakt antypaństwowej polityki kierownictwa „Bundu”. Wszak na początku maja 1920 r. MSW ostrzegło kierownictwo „Bundu” i „Poalej-Syjonu” przed kontynuowaniem działalności antypaństwowej, natomiast w lipcu

${ }^{62}$ Zob. list protestacyjny 73 polskich intelektualistów zamieszczony w „Robotniku” z 11 IX $1920 \mathrm{r}$.

${ }^{63}$ AAN, Akta Jana Kucharzewskiego, sygn. 2/2973/0, Pismo referenta Biura Propagandy Zagranicznej Prezydium Rady Ministrów z 30 IX 1920 r., nr L. 840/20/poufne pt. „Sprawa obozu w Jabłonnej”, b.m., k. 9. 
„Bund” już jawnie opowiedział się po stronie agresora ${ }^{64}$. Automatycznie nasuwa się pytanie: który europejski rząd $\mathrm{w}$ chwili śmiertelnego zagrożenia dla swego państwa i wrogiej postawy swoich mniejszości przeszedłby nad tym do porządku dziennego? Rozliczenia z kolaborantami powstrzymała dyplomacja amerykańska. Biały Dom złożył protest i wziął w obronę polskich Żydów. Dodatkowo protesty wewnątrz kraju skłoniły kierownictwo państwa i armii do rozwiązania obozu w Jabłonnie. Utrzymano jednak w mocy rozkaz o procentowym stosunku żołnierzy-Żydów do żołnierzy-Polaków i usunięciu z linii bojowej tych wszystkich, którzy przeszli przez obóz wojskowy w Jabłonnie. Po upływie stulecia sądzę, że utworzenie obozu w Jabłonnie zapewne było pokłosiem poufnego rozkazu Naczelnego Wodza o określeniu procentowego składu etnicznego oddziałów frontowych. Rekrutów żydowskiego pochodzenia zgromadzono w Jabłonnie w celu określenia ich dalszych przydziałów. Tyle że krytyczna sytuacja na froncie i trudności logistyczne opóźniły działanie biurokracji wojskowej. W następnych dniach podzielono żołnierzy-Żydów na trzy odrębne kategorie: 1 - pozostawionych w linii bojowej; 2 - przewidzianych do służby w wojskach etapowych; 3 - skierowanych do służb kwatermistrzowskich. Niestety, jak zawsze w takiej sytuacji, wielu lojalnych Żydów po prostu skrzywdzono i okrytą infamią, a członków jaczejek bolszewickich pozostawiono w spokoju. Warto pamiętać, że kilka tysięcy spolonizowanych Żydów, obywateli Rzeczypospolitej, zgłosiło się na ochotnika do Wojska Polskiego w chwili zagrożenia stolicy. Celowała w tym młodzież akademicka i gimnazjalna, która zareagowała na apel Rady Naczelnej Zjednoczenia Polaków Wyznania Mojżeszowego Wszystkich Ziem Polskich wzywający do masowego zaciągu do Wojska Polskiego. Tymczasem opisane wyżej restrykcje NDWP dotknęły nie tyle zbolszewizowanych proletariuszy żydowskich, co spolonizowanych Żydów. Ci reprezentowali ruch asymilatorski i przejawiali zdecydowanie propaństwową postawę.

\section{Nadzwyczajne środki do walki ze zbiegostwem latem 1920 roku}

Śmiertelne zagrożenie dla młodego państwa wymagało podjęcia specjalnych środków. W krytycznym momencie wojny latem 1920 r. wytoczono najcięższe działa przeciw dezerterom i osobom uchylającym się od służby wojskowej. Naczelny Wódz specjalnym rozkazem Nr 5268/20/Sąd. z dnia 23 lipca 1920 r. polecił zwierzchnikom karno-sądowym sądów polowych związków operacyjnych, wielkich jednostek, grup operacyjnych, etapów, twierdz, garnizonów

\footnotetext{
${ }^{64}$ CAW-WBH, Szefostwo Sądownictwa Polowego NDWP, sygn. I.301.21.19, Pismo okólne ministra spraw wewnętrznych do kierownictwa „Bundu” w Warszawie z dnia 4 V 1920 r. nr T.BB./109/i, b.m., b.p.; Okólnik ministra spraw wewnętrznych z dnia 10 VII 1920 r. nr T.BB.240/i., b.m., b.p.
} 
i szefom tych sądów zawieszenie śledztw i spraw karnych prowadzonych o dezercje. Rozkaz dotyczył śledztw wstępnych, dochodzeń, postępowań sądowych. Wprowadzono abolicję dla dezerterów i osób uchylających się od poboru. Dekret Naczelnego Wodza został upubliczniony w środkach masowego przekazu lub w postaci obwieszczeń i ogłoszony przed frontem każdej kompanii brzmiał następująco ${ }^{65}$ :

„Aby dać możność pozostającym pod śledztwem i odbywającym kary oficerom i żołnierzom stanąć w szeregi obrońców zagrożonej Ojczyzny, zarządzam tymczasowe wstrzymanie postępowania sądowego w sprawach karnych przeciwko oficerom i szeregowym, o ile rozchodzi się o przestępstwa mniejszej wagi. Decyzje, czy zachodzi powyższy przypadek poweźmie dowódca Okręgu Generalnego na zgodny wniosek sądu i prokuratora wojskowego. Oficerów i żołnierzy, co do których zapadła orzeczona decyzja, należy jak najszybciej wysłać na front. Należy ogłosić, że oficerowie lub szeregowi, przeciw którym w myśl niniejszego dekretu wstrzymano postępowanie, mogą na wypadek odznaczenia się w boju prosić o abolicję postępowania w drodze łaski.

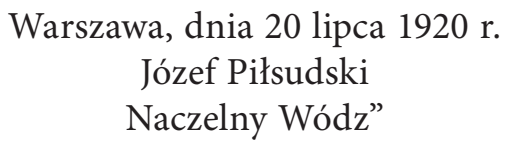

Oficerowie i żołnierze, przeciwko którym toczyły się sprawy sądowe za „przestępstwa mniejszej wagi”, zostali natychmiast zwolnieni z aresztów wojskowych i więzień. Dekret o abolicji nie objął szpiegów, dezerterów, którzy dopuścili się rabunków mienia przy użyciu broni, gwałcicieli i zabójców. Żołnierze zwolnieni z odwachów, aresztów i więzień zostali natychmiast wyekspediowani na front. W pośpiechu popełniono jednak mnóstwo błędów, w tym zagęszczenie niektórych pułków dezerterami, którzy skorzystali na abolicji. Po dokonaniu uzupełnień pułki powróciły w linię bojową, ale powtórne dezercje zredukowały ich faktyczną zdolność do walki. Tak było w przypadku 11 Dywizji Piechoty (DP), która po ciężkich walkach odwrotowych stopniała do wielkości słabego pułku piechoty. Po uzupełnieniu dezerterami, ozdrowieńcami i ochotnikami nie sprostała później pod kiepskim dowództwem wrogowi pod Radzyminem. Czy mogła jednak sprostać, gdy wyszło na nią natarcie dwóch doborowych dywizji bolszewickich, to już jest inna sprawa.

${ }^{65}$ CAW-WBH, Szefostwo Sądownictwa Polowego NDWP, sygn. I.301.21.19, Dekret Naczelnego Wodza ogłoszony rozkazem MSWojsk. Nr 440/1560/20 Oddz. VI K.P. Tjn. z 20 VII 1920 r., Warszawa, b.p. 
Poważny wysiłek organizacyjny w zaprowadzeniu porządku na zapleczu frontu włożył gen. Franciszek Latinik, który w chwili zagrożenia stolicy przybył z Krakowa. W dniu 28 lipca 1920 r. formalnie podporządkowano mu 1 Armię WP, która była trzonem wojsk Frontu Północnego i cały obszar DOGen. Warszawa ze stolicą włącznie. Po mianowanie go Wojskowym Gubernatorem Warszawy, gen. Latinik skorzystał z nadzwyczajnych uprawnień po wprowadzeniu w Warszawie stanu oblężenia i wejściu w kompetencje zwierzchnika sądo-

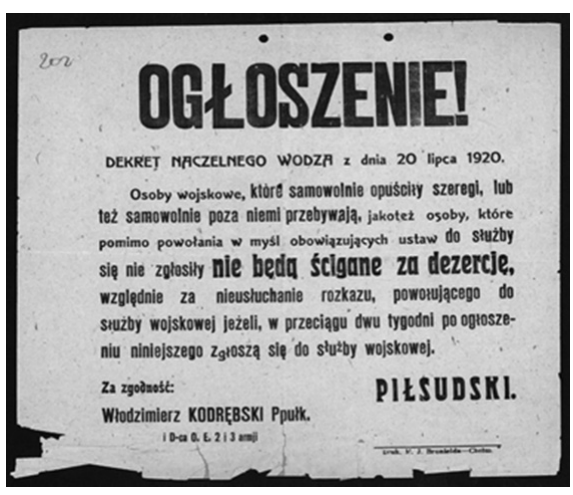

Jedno z obwieszczeń abolicyjnych adresowane do dezerterów

Źródło: AAN, Akta instytucji wojskowych 1918-1939, sygn. 296-I-56, k. 202. wego dla wyroków sądów doraźnych

działających w stolicy ${ }^{66}$. W rozkazach do dywizji 1 Armii WP i wszystkich formacji wojskowych na przedmościu warszawskim gen. Latinik zagroził oddaniem każdego żołnierza pod sąd doraźny za dezercję lub opuszczenie linii bojowej ${ }^{67}$. Osiągnięciem NDWP i dowództw oddziałów zapasowych było wyprawienie na front największej możliwej liczby zdolnych do walki oficerów i żołnierzy. Już kilka tygodni wcześniej oficerowie Francuskiej Misji Wojskowej zwrócili NDWP uwagę na zachwianie proporcji między stanem bojowym wojsk a stanem żywionym. Innymi słowy, stosunek liczby żołnierzy w linii bojowej do stacjonujących na tyłach wynosił 1 do 2,5. Szef Francuskiej Misji Wojskowej w Warszawie, gen. Paul Henrys, zauważył w memorandum skierowanym w dniu 3 sierpnia 1920 r. do MSWojsk., że nadmierna liczba żołnierzy w taborach, konwojach i na zapleczu oraz niekontrolowany odpływ całych grup z linii bojowej na tyły „nie pozwala NDWP na aktualną ocenę wartości bojowej poszczególnych oddziałów". To automatycznie wiązało się z przydzielaniem zadań bojowych, uzupełnieniem $\mathrm{w}$ środki walki i zasileniem nowymi ludźmi ${ }^{68}$. Uwagi zostały przez NDWP przyjęte i przetworzone na rozkazy.

Od końca czerwca 1920 r. kierownictwo państwa i dowództwo sił zbrojnych w związku z niekorzystną sytuacją na frontach, po dokładnej analizie raportów kierownictwa Żandarmerii, wysłanników NDWP i oficerów ds. specjalnych poruczeń wizytujących dywizje 1 Armii WP w linii bojowej,

\footnotetext{
${ }^{66}$ W czasie bitwy warszawskiej Okręgi Etapu zmieniły nazwę na Etapy, by we wrześniu 1920 r. powrócić do dawnej nazwy.

${ }^{67}$ K. Klimaszewski, M. Pakuła, Bitwa Warszawska..., s. 246.

${ }^{68}$ Bitwa lwowska..., cz. I, s. 828-829.
} 
podjęło szereg działań w celu wzmocnienia morale i dyscypliny walczących wojsk. Działania te przybrały postać reorganizacji formacji sądowo-policyjnych w przededniu bitwy o Warszawę, gdyż musiały się zmierzyć ze zjawiskiem masowych dezercji z frontu. Pośród nich najważniejszą rolę odegrały kordony przeciwdezercyjne, obławy na dezerterów, stacje zborne dla żołnierzy poszukujących swoich oddziałów, obozy koncentracyjne i zaostrzenie prawa wojennego. Władze wojskowe wypowiedziały zdecydowaną walkę najgroźniejszym przestępstwom wojskowym, które godziły wprost w morale żołnierzy, dyscyplinę i zdolność bojową oddziałów w linii bojowej. Dekretem Naczelnego Wodza datowanym na 26 czerwca 1920 r., a wprowadzonym w życie rozkazem Głównego Kwatermistrza WP i szefa służby sądowo-polowej Nr 5223/20/Sąd. taksatywnie określono katalog zbrodni i przestępstw, które zostały przekazane do właściwości sądów doraźnych w obliczu zagrożenia państwa. W katalogu najbardziej groźnych zbrodni i przestępstw wojskowych nie zabrakło penalizacji tchórzostwa w obliczu nieprzyjaciela, dezercji, grupowej dezercji i karalnego pomocnictwa do dezercji ${ }^{69}$. Te cztery kategorie przestępstw wojskowych były szczególnie niebezpieczne dla utrzymania zwartości i zdolności bojowej oddziałów frontowych. Naczelne Dowództwo WP w przededniu decydującej bitwy nad Wisłą uruchomiło na Przedmościu Warszawskim lotne sądy doraźne $e^{70}$. W stolicy utworzono Straż Obywatelską, do której ochotniczo zgłosiło się 16 tys. mężczyzn i kobiet powyżej 35 roku życia spośród osób z różnych względów nie podlegjących wcieleniu do wojska. Z inicjatywą powołania Straży Obywatelskiej, która miała zwolnić z ulic Warszawy na front formacje policyjne i wojskowe, wystąpiło wiele stołecznych organizacji jak: Koło Przemysłowców, Liga Antybolszewicka, Stowarzyszenie Robotników Chrześcijańskich, stołeczny „Sokół”, Stowarzyszenie Właścicieli Nieruchomości, organizacje rzemieślnicze, kupieckie i korporacje wolnych zawodów. We władzach Straży Obywatelskiej dominowali warszawscy adwokaci i kupcy o korzeniach endeckich ${ }^{71}$.

W rozkazie Nr 8177/III z dnia 30 lipca 1920 r. szef Sztabu Generalnego WP, gen. Tadeusz Rozwadowski, wezwał wszystkich dowódców wojskowych do użycia „wszelkich środków i nie cofnąć się przed najbardziej drakońskimi zarządzeniami”72. Oprócz wojskowych lotnych sądów doraźnych

${ }^{69}$ CAW-WBH, Szefostwo Sądownictwa Polowego NDWP, sygn. I.301.21.22, Dekret Naczelnego Wodza z 26 VI 1920 r., Nr 5223/20/Sąd, Warszawa, b.p.

${ }^{70}$ Reorganizacja sądownictwa wojskowego do Bitwy Warszawskiej i działalność orzecznicza sądów wojennych NDWP została szczegółowo przedstawiona w monografii L. Kani, Wyroki bez apelacji..., s. 225-279 i idem, Organizacja i rys działalności... (część 2)...

${ }^{71}$ Zob. Komunikat Informacyjny $n r 44$ (111) $z$ dnia $5.08 .1920 \mathrm{r}$. [w:] O niepodległa i granice..., s. 514.

${ }^{72}$ Bitwa lwowska..., cz. I, s. 874. 
i terytorialnych Sądów Wojskowych przy DOGen. rozpoczęły działalność komisje sądzące, które zaczęto tworzyć w garnizonach na zapleczu frontu. Komisje te składały się z oficerów WP i żandarmów, zaś przedmiotem ich działania było wydawanie wyroków na dezerterów w trybie postępowania doraźnego. $\mathrm{W}$ batalionach zapasowych i garnizonach na zapleczu frontu naprędce tworzono plutony egzekucyjne, które przystąpiły do wykonywania wyroków orzeczonych przez komisje sądzące i sądy powszechne. Informacje o wykonanych wyrokach śmierci ogłaszano w postaci obwieszczeń publicznych, które wywarły odpowiednie wrażenie ${ }^{73}$. Na murach miast i miasteczek pojawiły się plakaty propagandowe i obwieszczenia zawierające sentencje wyroków sądów polowych skazujących na najwyższy wymiar kary za dezercje i szpiegostwo.

Zasadniczy wysiłek w zwalczaniu dezercji spoczął na Żandarmerii Polowej. Formacja ta już na początku maja 1920 r. utworzyła kordon sanitarny na Dniestrze w celu powstrzymania epidemii chorób zakaźnych poprzez wprowadzenie drastycznych ograniczeń w ruchu ludności cywilnej ${ }^{74}$. Rozkazami NDWP datowanymi na 28 lipca 1920 r. i 1 sierpnia 1920 r. wzdłuż frontu biegnącego z północy na południe bezpośrednio za linią walczących wojsk rozciągnięto kordon, który składał się z żandarmów, funkcjonariuszy Policji Państwowej i żołnierzy wojsk etapowych ${ }^{75}$. Kordon miał „powstrzymać niedozwolony ruch $\mathrm{z}$ linji bojowej ku tyłom, walkę z dezercją, łazikostwem, szerzeniu się paniki i popłochu"76. Linia kordonu przebiegała przez stolice powiatów, co miało zaktywizować miejscowe dowództwa, wojska etapowe i służby policyjne oraz włączyć miejscowe władze do udzielenia pomocy Żandarmerii Polowej. Kordon przeciwdezercyjny został podzielony na części według następującego schematu ${ }^{77}$ :

1. element kordonu odpowiadający długości linii bojowej zajmowanej przez front (armię);

2. odcinek kordonu odpowiadający długości linii frontu zajmowanej przez dywizję (brygadę);

\footnotetext{
${ }^{73}$ L. Kania, Wyroki bez apelacji..., s. 266, 345.

${ }^{74}$ Zob. G. Ratajczyk, Żandarmeria Wojska Polskiego..., s. 146-147.

${ }^{75}$ CAW-WBH, Dowództwo Żandarmerii 1918-1939, sygn. I.300.51.31, Rozkaz NDWP z 28 VII 1920 r. Nr Żand. 1835/20.Pf.Org., b.m., b.p.; Rozkaz ND WP z 1 VIII 1920 r. Nr Żand. 1869/20.Pf.Org., b.m., b.p.

${ }^{76}$ CAW-WBH, Szefostwo Sądownictwa Polowego NDWP, sygn. I.301.21.22, „Instrukcja do pełnienia służby w kordonie” wprowadzona rozkazem NDWP z 7 VIII 1920 r. Nr. Żand. 1940/20/ Pf.Org., b.m., b.p.

${ }^{77}$ Ibidem.
} 
3. pododcinki kordonowe wytyczone w większych zbiorowiskach ludzkich (miasteczkach, dużych wioskach) i newralgicznych miejscach na tyłach walczących wojsk;

4. posterunki kordonowe usytuowane na skrzyżowaniach dróg, na dworcach kolejowych i węzłach komunikacyjnych, brodach i mostach.

$\mathrm{Za}$ organizację i bieżące funkcjonowanie kordonu na szczeblu frontu (armii) odpowiadał Kwatermistrz frontu (armii), który w tym zakresie działał poprzez podległego mu dowódcę frontowej (armijnej) żandarmerii. Na szczeblu dywizji (brygady) za funkcjonowanie kordonu odpowiadał dowódca plutonu Żandarmerii Polowej szczebla dywizji, zaś za pododcinki i posterunki żandarmerii komendanci dowództw etapowych do szczebla powiatu włącznie. Najniższym organem kordonowym był komendant posterunku na kordonie, którym z założenia był oficer, względnie doświadczony podoficer Żandarmerii Polowej, który miał do dyspozycji od 6 do 40 żandarmów, funkcjonariuszy Policji Państwowej lub żołnierzy wojsk etapowych. Pełniący służbę na kordonie mieli następujące obowiązki:

1. kontrolę wszystkich osób wojskowych i cywilnych udających się na front lub odchodzących $z$ linii bojowej na tyły pojedynczo lub w składzie oddziałów wojskowych bez względu na ich stopnie wojskowe;

2. kontrolę pojazdów, motocykli, wozów konnych i tożsamości ich pasażerów za wyjątkiem tych, które należą do dowództw frontów (armii). Te ostatnie mają prawo kontrolować tylko oficerowie Żandarmerii Polowej;

3. przepuszczanie przez kordon kurierów wyposażonych w odpowiednie dokumenty, hasła i znaki kurierskie;

4. zatrzymywanie rannych i odsyłanie ich do obozów koncentracyjnych;

5. zatrzymywanie dezerterów, żołnierzy bez przydziału i tzw. łazików;

6. kontrolowanie ruchu taborów przez linię kordonową.

Organizacja kordonu wzorowała się na sprawdzonym systemie zastosowanym w armiach europejskich w czasie I wojny światowej. „Instrukcja” zakazywała prowadzenia biurokracji na posterunkach kordonowych. Od żandarmów oczekiwano szybkich, zdecydowanych działań. Rannych nie odsyłano automatycznie do szpitali, lecz do obozów koncentracyjnych. Dopiero tam badano ich stan zdrowia i decydowano o hospitalizacji. To wiązało się z dużym odsetkiem rannych w następstwie samopostrzeleń, których oddawano pod sąd polowy lub zawracano na front. Przyjęto założenie, że żołnierz ranny $\mathrm{w}$ linii bojowej podlegał zorganizowanej ewakuacji na tyły tylko poprzez służby medyczne. Poza sytuacją rozerwania frontu przez przeciwnika żołnierz ranny na polu walki nie miał prawa szukać pomocy medycznej na tyłach na własną rękę. Dezerterów, „łazików” i podejrzanych cywilów miano odstawiać do dowództw pododcinków na kordonie, skąd mieli być konwojowani do obozów koncentracyjnych. Po doświadczeniach ostatniej wojny obóz koncentracyjny kojarzy się jednoznacznie z miejscem zagłady. Tymczasem 
w czasie wojny z Rosją bolszewicką obozy koncentracyjne pełniły rolę stacji rozdzielczych lub stacji zbornych. Po ustaleniu tożsamości, wyjaśnieniu przyczyn zatrzymania na kordonie i po wstępnej selekcji doprowadzonych żołnierzy i osób cywilnych funkcjonariusze defensywy, oficerowie poborowi i żandarmi decydowali o ich dalszym losie. Większość zdolnych do walki żołnierzy kierowano ponownie na front, rannych i kontuzjowanych odsyłano do szpitali, a podejrzanych osadzano w aresztach do dyspozycji organów śledczych i sądowych. W rażących przypadkach sprawcy najcięższych zbrodni byli odstawiani do wojskowych sądów doraźnych, gdzie mogli spodziewać wyroków śmierci. Szybkie postępy Armii Czerwonej w sierpniu 1920 r. w praktyce zniweczyły jednak możliwość postawienia kordonów Żandarmerii Polowej za linią bojową. Przez krótki czas, tj. kilka dni pierwszej dekady sierpnia 1920 r., funkcjonował kordon przeciwdezercyjny postawiony przez Żandarmerię Polową przy wsparciu służb policyjnych na odcinku MławaCiechanów-Nasielsk-Zegrze-Radzymin-Wawer-Kołbiel-Garwolin-Dęblin ${ }^{78}$. W dniach 10-12 sierpnia 1920 r., tuż za linią bojową dywizji 1 Armii WP, na których spoczywał ciężar obrony Warszawy, ustawiono siedem odcinków kordonowych z 31 posterunkami Żandarmerii Polowej. Tylko w pierwszych dwóch tygodniach sierpnia 1920 r. żandarmi z tego kordonu ujęli i przekazali do stacji zbornych 759 żołnierzy wałęsających się bez przydziału lub poszukujących macierzystych oddziałów ${ }^{79}$.

Planowana sieć kordonów ze względu na szybkie postępy Armii Czerwonej sprowadziła się do utworzenia ciągłego kordonu. Niektóre oddziały Żandarmerii Polowej zostały doraźnie włączone do walczących wojsk. W skład kordonu weszły plutony żandarmerii z 1 Dywizjonu Żandarmerii w Warszawie w sile ok. 300 ludzi, które wzmocniły etapowe plutony żandarmerii. Przesunięcie linii frontu na teren OGen. Warszawa, Lublin i Lwów pozwoliły na włączenie do kordonu wszystkich sił policyjno-wojskowych tych okręgów. Przed wyprowadzeniem kontrnatarcia znad Wieprza Żandarmerii Polowej udało się utworzyć szczelny kordon na linii środkowej Wisły i Sanu ${ }^{80}$. Ustawienie w miarę szczelnego kordonu i zaangażowanie stosunkowo dużych sił policyjno-wojskowych pozwoliło na przeprowadzenie cyklicznych obław na dezerterów, mężczyzn uchylających się od poboru i osób podejrzanych o działalność antypaństwową. Z badań Przemysława Bednarczyka i Sebastiana Piątkowskiego wynika, że liczba dezerterów i popisowych uchylających się

\footnotetext{
${ }^{78}$ CAW-WBH, Dowództwo Żandarmerii 1918-1939, sygn. I.300.51.31, Rozkaz Dowódcy Żandarmerii Polowej z 5 VIII 1920 r. nr L.dz.1153/pf/20. o utworzeniu kordonu przez Żandarmerię Polową, b.m., b.p.

${ }^{79}$ J. Suliński, Żandarmeria organ bezpieczeństwa armii 1918-1945, Warszawa 2003, s. 77.

${ }^{80}$ Ibidem, s. 71-72. Zob. plan rozmieszczenia kordonów za linią bojową lub plany w tym zakresie: CAW-WBH, Dowództwo Ekspozytur Żandarmerii Polowej, sygn. I.375.20.2.
} 
od poboru zwiększyła się po przekroczeniu linii Bugu przez Armię Czerwoną, natomiast zmniejszyła się po nadejściu pomyślnych informacjach $\mathrm{z}$ frontu ${ }^{81}$. W lipcu i sierpniu 1920 r. na terenie działania Dywizjonu Żandarmerii w Kielcach aresztowano co najmniej 6 tys. dezerterów i mężczyzn uchylających się od poboru ${ }^{82}$. Ludzie ci zostali zawróceni do oddziałów zapasowych, z których pomaszerowali na front lub stanęli przed sądem doraźnym. Pod wpływem retoryki premiera Witosa stopniowo poprawiała się atmosfera na wsi polskiej. W lipcu 1920 r. zatrzymano w powiecie iłżeckim 50 mężczyzn uchylających się od poboru, w sierpniu 170, zaś we wrześniu tylko 84 osoby ${ }^{83}$. W październiku ujęto 30 osób, co trzeba tłumaczyć radykalną zmianą nastrojów społecznych po sukcesie kontrofensywy sierpniowej. W drugim roku wojny z Rosją bolszewicką odnotowano, rzecz jasna, więcej przypadków dezercji niż w pierwszym, albowiem armia była też kilkakrotnie większa.

Kordony przeciwdezercyjne były sprawdzoną w latach Wielkiej Wojny metodą wyłapywania zbiegów z linii bojowej, zawracania dezerterów na front i stawiania ich do dyspozycji organów policyjno-sądowych. To automatycznie wiązało się z podziałem obszaru wojennego na rejony i obwody przeciwdezercyjne, a celem tego przedsięwzięcia był jasny przekaz do wszystkich żołnierzy na froncie: „ucieczka na tyły grozi represjami i śmiercią!”. Rozkazem Ministra Spraw Wojskowych datowanym na 23 lipca 1920 r. wszystkie OGen. zostały podzielone na okręgi przeciwdezercyjne. Od początku lipca do września 1920 r. każdy z 22 okręgów przeciwdezercyjnych został podzielony na 2-3 rejony przeciwdezercyjne. $Z$ kolei każdy rejon obejmował kilka powiatów. Rejony przeciwdezercyjne w ostatnich dniach listopada 1920 r. przekształcono w rejony bezpieczeństwa ${ }^{84}$. W rejonach tych regularnie przeprowadzano obławy policyjne na zbiegów z oddziałów frontowych i osoby uchylające się od poboru do wojska. Na zaplecze frontu wyruszyły lotne oddziały Żandarmerii Polowej. Ujętych dezerterów oddawano pod sądy doraźne, które miały orzekać kary śmierci w razie stwierdzenia winy, zaś osoby udzielające dezerterom pomocy były zagrożone karą $\mathrm{w}$ wymiarze od czterech lat ciężkiego więzienia do kary śmierci. W przełomowym okresie wojny, tj. latem 1920 r., wysiłek w ściganiu osób uchylających się od poboru i dezerterów spoczął także na organach policyjnych. Policja Państwowa zasiliła kadrowo i organizacyjnie szczupłe siły Żandarmerii Polowej, gdyż na mocy rozporządzenia Rady Obrony Państwa z 6 sierpnia 1920 r. w sprawie tymczasowych zmian dotyczących organizacji i zadań Policji Państwowej stała się integralną częścią sił zbrojnych i uzyskała status

\footnotetext{
${ }^{81}$ P. Bednarczyk, S. Piątkowski, „Twierdza nam będzie każdy próg...”, s. 94 i n.

${ }^{82}$ J. Suliński, Żandarmeria..., s. 99.

${ }^{83}$ W. Jarno, Okręg Generalny WP nr III Kielce..., s. 148.

${ }^{84}$ L. Kania, Wyroki bez apelacji..., s. 299.
} 
organu bezpieczeństwa państwa. W konsekwencji wszystkie przestępstwa jej funkcjonariuszy zostały poddane właściwości sądów doraźnych ${ }^{85}$. W głębi kraju to nie Żandarmeria Wojskowa, ale Policja Państwowa miała gęstą sieć informatorów i możliwości wyłuskiwania dezerterów i osób uchylających się od poboru. „Gazeta Śledcza” wydawana przez Wydział Rejestracyjno-Karny Komendy Głównej PP każdego dnia zamieszczała listy gończe za dezerterami i osobami uchylającymi się od poboru. Poszukiwani za naruszenie obowiązku wojskowego byli ścigani w pierwszej kolejności, a służby policyjne odniosły na tym polu poważne sukcesy ${ }^{86}$.

W lipcu 1920 r. w warszawskiej Cytadeli utworzono obóz koncentracyjny z przeznaczeniem dla dezerterów. W okresie od 1 czerwca do 20 września 1920 r. w Tarnobrzegu działał obóz koncentracyjny dla dezerterów i rozbitków z frontu z wszystkich oddziałów wchodzących w skład 3 Armii WP. Tam segregowano żołnierzy na zbiegów z frontu i maruderów poszukujących macierzystych jednostek, po czym jednych oddawano pod sąd polowy, a drugich ekspediowano do macierzystych jednostek ${ }^{87}$. Obóz koncentracyjny dla dezerterów i osób uchylających się od poboru w pasie działania 5 Armii WP utworzono w twierdzy Modlin, zaś w pasie działania 2 Armii WP w Zawidowie. Na terenie stolicy i podstołecznych powiatów z dniem 10 sierpnia 1920 r. ogłoszono stan oblężenia i wprowadzono bezwzględną prohibicję ${ }^{88}$. Żandarmi legitymowali mężczyzn na ulicach, wygarniali pasażerów z tramwajów i sprawdzali, czy wśród nich nie ma uchylających się przed wcieleniem do wojska ${ }^{89}$. Żywiołowo pomagali im w takich czynnościach cywile, zwłaszcza młodzi harcerze, starsi mężczyźni i kobiety. W ciągu kilku dni gen. Latinik jako wojskowy gubernator Warszawy wydał wiele zarządzeń, które penalizowały wszelkie nieposłuszeństwo władzom wojskowym, przebywanie w Warszawie oficerów i żołnierzy bez przydziału, obowiązek rejestracji obywateli w wieku od 15 do 50 lat, przymusową rekwizycję na rzecz walczącej armii żywności, bydła rzeźnego, zakaz lichwy itd. Wprowadzono nową politykę przeciwdziałania dezercji i przestępstwom przeciwko obowiązkowi wojskowemu. Nowy kurs sprowadzał się do równoległego wykonania wielu skomplikowanych przedsięwzięć. Dozorcy i zarządcy

${ }^{85}$ Zob. treść rozporządzenia Dz.U. R.P. 1920, nr 75, poz. 511.

${ }^{86}$ Zob. liczne listy gończe Głównej Centrali Inwigilacyjnej (IV Wydziału Rejestracyjno-Karnego) Komendy Głównej Policji Państwowej w Warszawie i raporty o zatrzymaniach dezerterów i osób uchylających się od poboru w odpisach i fotokopiach w CAW-WBH, Dowództwo Żandarmerii 1918-1939, sygn. I.300.51.36-38.

${ }^{87}$ Bitwa lwowska..., cz. II, s. 316-317.

${ }^{88}$ P. K. Marszałek, Wojskowy Gubernator Warszawy. Sierpień-wrzesień 1920 roku, „Acta Universitatis Wratislaviensis" 2004, nr 2616, s. 250 i n.

${ }^{89}$ N. Davies, Orzet biały..., s. 235. 
budynków mieszkalnych zostali zobowiązani do powiadamiania organów policyjnych o każdym żołnierzu przebywającym w domu przez czas dłuższy niż 12 godzin ${ }^{90}$. Studentki w Lublinie wręczały przechodniom ulotki z tekstem: „Dlaczego jesteś jeszcze tutaj, a nie na froncie?”"1. Komórki odpowiedzialne za propagandę i werbunek ochotników do wojska propagowały wyszydzanie i bojkot towarzyski tych mężczyzn, którzy nie zaciągnęli się w szeregi wojska. Rzecz jasna, to dotyczyło tylko tych mężczyzn, którzy nie spełniali warunków dla przymusowego wcielenia ${ }^{92}$.

Wieczorem 15 sierpnia 1920 r. gen. Józef Haller rozkazał utworzyć na tyłach walczących wojsk linię kordonową i wprowadzić oddziały zaporowe w celu powstrzymania dezercji z prawem użycia broni włącznie ${ }^{93}$. Ten wyjątkowy i drastyczny krok spowodowany był paniczną ucieczką dwóch batalionów 46 pp z 11 DP spod Radzymina. Rozkaz ten był o tyle spóźniony, że linia kordonu funkcjonowała już wcześniej za linią bojową 1 Armii WP. Poza tym po przejściu do kontrofensywy wojsk polskich nie było warunków do postawienia i utrzymania kordonu za szybko przemieszczającymi się polskimi pułkami. Na mocy przepisów Rozporządzenia Rady Obrony Państwa z dnia 11 sierpnia $1920 \mathrm{r}$. dezerter z WP mógł zostać pozbawiony obywatelstwa polskiego ${ }^{94}$. Takie konsekwencje groziły też małżonkowi dezertera i małoletnim dzieciom poniżej 18. roku życia. Utrata obywatelstwa za uchylanie się od wykonania obowiązku służby wojskowej groziła także osobom przebywającym poza granicami kraju, które po ogłoszeniu mobilizacji powszechnej zaniechały zgłoszenia się w polskich placówkach dyplomatycznych w celu wyjaśnienia swojej sytuacji prawnej ${ }^{95}$.

Po odwróceniu losów wojny i przed bitwą nad Niemnem dezercja z linii bojowej ustała lub przestała być problemem dla dowódców. Zmienił się także stosunek społeczeństwa polskiego do opromienionej zwycięstwem własnej armii. W pierwszym rzędzie diametralnie zmienił się stosunek do Wojska Polskiego ze strony ludności wiejskiej. Mniejszości narodowe po bitwach pod Warszawą, Lwowem i nad Niemnem stały się bardziej spolegliwe i zastygły $\mathrm{w}$ bolesnym milczeniu. Pozostało rozliczyć się z tymi, którzy zawiedli w godzinie próby. W sukurs sądom polowym i służbom wojskowo-policyjnym ponownie przyszedł Naczelny Wódz, który w dniu 20 września 1920 r. wydał kolejny dekret abolicyjny. Był on ważny z punktu widzenia losów tysięcy ludzi, więc warto przytoczyć jego fragment:

\footnotetext{
${ }^{90}$ Ibidem.

${ }^{91}$ M. Olczak, J. Stryjek, Album..., s. 192-193.

${ }^{92}$ Ibidem, s. 194.

${ }^{93}$ M. Orłowski, Generał Józef Haller 1873-1960, Kraków 2007, s. 345.

${ }^{94}$ Dz.U. RP 1920, nr 81, poz. 540.

${ }^{95}$ Ibidem.
} 
„W tej podniosłej chwili, nie chcąc ścigać surowymi karami tych, którzy pod wpływem przemijającego upadku ducha czyniąc sami sobie krzywdę największą uchylili się od wspólnego dzieła ze swymi zwycięskimi towarzyszami broni oraz aby dać im możność okupienia popełnionego błędu dalszą pracą żołnierską,- zarządzam co następuje: osoby wojskowe, które w chwili ogłoszenia niniejszego Dekretu pozostają poza szeregami wskutek samowolnego opuszczenia lub wskutek samowolnego powstrzymania się od powrotu do szeregów nie będą podlegały ściganiu według przepisów o sądach doraźnych, o ile najpóźniej do dnia 4 października r.b. zgłoszą się do służby wojskowej u najbliższej władzy wojskowej. W wypadku skazania tych osób w drodze postępowania zwykłego, Minister Spraw Wojskowych oraz właściwi dowódcy czynić będą stosownie do ujawnionych okoliczności sprawy użytek z przysługującego im prawa zawieszania kary aż do ukończenia działań wojennych. W wypadkach zasługujących na szczególne uwzględnienie, będzie stosowane prawo łaski" ${ }^{\prime 96}$.

Po victorii niemeńskiej zaczęła się demobilizacja sił zbrojnych, co wraz z rychłym końcem działań wojennych uspokoiło nastroje w społeczeństwie. Na froncie ustały dezercje, a w głębi kraju nie potrzebowano już tysięcy rekrutów. Pozostały tylko złe emocje i bolesna pamięć. Do następnej wojny.

\section{Zakończenie}

W latach 1918-1921 przez szeregi wojska przeszło ok. 1,2 mln oficerów i żołnierzy, z których w czasie dwuletniej wojny z Rosją bolszewicką zdezerterowało ok. 80 tys. żołnierzy, a 120-150 tys. rekrutów w karalny sposób uchylało się od poboru do wojska. Dane te mogą dziś szokować, ale w żadnej mierze nie odbiegają od przeciętnych zachowań populacji męskiej każdego kraju w czasie wojny. W szczytowym okresie wojny w siłach zbrojnych służyło co najmniej 940 tys. oficerów i żołnierzy, nie licząc formacji wojsk sprzymierzonych. W tej milionowej armii, której co najmniej 80\% stanowili żołnierze z przymusowego poboru, dezercje były zjawiskiem stałym, zwłaszcza po czterech latach wielkiej europejskiej rzezi, która pozbawiła życia lub okaleczyła milion Polaków. W drugim roku wojny z Rosją bolszewicką odnotowano więcej przypadków dezercji, gdyż armia była kilkakrotnie większa. Doniesienia o okrucieństwie bolszewików i wstrząsające relacje uciekinierów z Rosji w znacznym stopniu zmieniły podejście społeczeństwa

\footnotetext{
${ }^{96}$ CAW-WBH, Szefostwo Sądownictwa Polowego NDWP, sygn. I.301.21.22, Rozkaz Naczelnego Dowództwu WP i Szefa Służby Sądowo-Polowej NDWP Nr 8553/20/Sąd. z 23 IX 1920 r., b.m., b.p.
} 
do armii. Po sukcesach ofensywy sierpniowej zasadniczo zmienił stosunek polskiej opinii publicznej do dezerterów. Coraz częściej na obszarach wiejskich osobom uchylającym się od poboru i dezerterom odmawiano schronienia lub wydawano zbiegów policji i żandarmerii. Znaczny odsetek rekrutów z roczników 1896-1901 nie miał wcześniej kontaktu z bronią, musztrą i regulaminami. W drugiej połowie lipca i w sierpniu 1920 r., czyli w szczytowym okresie wojny, tylko z Warszawy wyekspediowano na front ok. 80 tys. ochotników, a ogółem 105 tys. Mimo braku wyszkolenia i doświadczenia bojowego ochotnicy wnieśli ducha walki i entuzjazm w szeregi weteranów. Do wojska zgłaszali się warszawscy inteligenci, czyli nauczyciele, naukowcy, aktorzy, inżynierowie, adwokaci, literaci, urzędnicy i młodzież gimnazjalna. Zdarzało się jednak, że ludność folwarczna miejscami sprzyjała agresorowi i uległa bolszewickiej propagandzie.

Mniejszości narodowe zamieszkujące państwo polskie generalnie nie okazały się lojalne wobec swoich sąsiadów. Mniejszość niemiecka, litewska i ukraińska wieś otwarcie okazywały sympatię dla bolszewików. Do Wojska Polskiego garnęli się tylko Białorusini i spolonizowani Żydzi, mniejszość żydowska w czasie inwazji bolszewickiej podzieliła się bowiem na część diaspory lojalną wobec Rzeczypospolitej (inteligencja, mieszczaństwo, burżuazja) i część, która okazała wrogość wobec państwa polskiego (proletariat, biedota, młoda inteligencja). Przejawiało się to w kontestowaniu swoich obowiązków wobec Rzeczypospolitej, w tym wykonania obowiązku służby wojskowej.

\section{Bibliografia}

\section{Archiwalia}

Archiwum Akt Nowych

Akta instytucji wojskowych 1918-1939

Prezydium Rady Ministrów

Związek Harcerstwa Polskiego

Centralne Archiwum Wojskowe Wojskowego Biura Historycznego

Dowództwo Ekspozytur Żandarmerii Polowej 1919-1922

Dowództwo Żandarmerii 1918-1939

Oddział VI Prawny Sztabu MSWojsk.

Rozkazy Poufne Dowództwa Okręgu Korpusu Grodno 1920 r.

Sądownictwo Polowe NDWP

Szefostwo Sądownictwa Polowego NDWP

\section{Źródła drukowane}

Bitwa lwowska 25 VII - 18 X 1920. Dokumenty operacyjne, cz. 1: 25 VII - 5 VIII, Warszawa 2002; cz. 2: 6 - 20 VIII, wyb. oprac. i red. zespół pod kier. M. Tarczyńskiego, Warszawa 2004. 
Bitwa niemeńska: 29 VIII - 18 X 1920. Dokumenty operacyjne, cz. 1: 29 VIII - 19 IX, Warszawa 1998; cz. 2: 20 IX - 18 X, wyb. oprac. i red. zesp. pod kier. M. Tarczyńskiego, Warszawa 1999.

Bitwa warszawska 13-28 VIII 1920. Dokumenty operacyjne, cz. 1: 3-17 VIII, wyb. oprac. i red. zesp. pod kier. M. Tarczyńskiego, Warszawa 1995; cz. 2: 17 - 28 VIII, wyb. oprac. i red. zesp. pod kier. M. Tarczyńskiego, Warszawa 1996.

O niepodległa i granice, t. 2: Raporty $i$ komunikaty naczelnych władz wojskowych o sytuacji wewnętrznej Polski 1919-1920, oprac. i wyb. M. Jabłonowski, P. Stawecki, T. Wawrzyński, Warszawa-Pułtusk 2000.

Odrodzenie Wojska Polskiego 1918-1921 w materiałach CAW, red. A. Wesołowski, Warszawa 2008.

Rok 1920 w obrazie i dokumencie. Wojna z bolszewikami w zbiorach archiwów polskich, red. M. Olczak, J. Stryjek, Warszawa 2020.

\section{Wspomnienia}

S. Grabski, Pamiętniki, t. II, Warszawa 1989.

T. Kossak, Wspomnienia wojenne (1918-1920), Kraków 1925.

\section{Literatura}

Baczkowski M., Pod czarno-żółtymi sztandarami. Galicja i jej mieszkańcy wobec austro-węgierskich struktur militarnych 1868-1914, Kraków 2003.

Bednarczyk P., Piątkowski S., „Twierdza nam będzie każdy próg...”. Społeczeństwo Ziemi Radomskiej w okresie wojny polsko-bolszewickiej lat 1919-1920, Radom 2015.

Bitwa Warszawska 1920 roku w obronie niepodległości, red. J. Odziemkowski, Warszawa 2006.

Bizan S., Powiat i miasto Brodnica w walkach o niepodległość 1914-1920 rok, Brodnica 1939.

Borek P., Działalność siedleckiego komitetu wojskowo-rewolucyjnego w sierpniu 1920 roku, „Komunizm: System-Ludzie-Dokumentacja” 2014, nr 3.

Borek P., Postawa społeczeństwa południowego Podlasia wobec kontruderzenia znad Wieprza w sierpniu 1920 roku., „Radzyński Rocznik Humanistyczny” 1920, nr 8.

Chodkiewicz K., Stępek W., Stużba wywiadowcza i ochrona przeciwszpiegowska, Poznań 1925.

Cygan J., Cygan W. K., Rok 1920 na Ziemi Mińskiej, Mińsk Mazowiecki 2010.

Dauksza M., Siedlczanie wobec bolszewickiej inwazji 1920 r., „Prace Archiwalno-Konserwatorskie na terenie województwa siedleckiego” 1997, z. 10.

Davies N., Orzeł biały, czerwona gwiazda. Wojna polsko-bolszewicka 1919-1920, Kraków 2011.

Dębiński J., Inwazja bolszewicka na Ziemi Dobrzyńskiej i Kujawach wschodnich, „Grot. Zeszyty Historyczne” 2005, nr 24.

Drozdowski M., Warszawa w obronie Rzeczypospolitej czerwiec-sierpień 1920, Warszawa 1993. 
Ejsmond P., Przestępstwo dezercji. Rys prawno-historyczny, „Przegląd Morski” 1984, z. 7-8.

Gontarek A., Żydzi Mińska Mazowieckiego w latach 1918-1939, Lublin 2015.

Grzegorczyk T., 6 Armia Wojska Polskiego w 1920 r., Toruń 2009.

Helma S., Dezinformacja i wojna psychologiczna jako element polityki Związku Sowieckiego i Federacji Rosyjskiej, „Zeszyty Naukowe Towarzystwa Doktorantów UJ Nauki Społeczne" 2018, nr 3.

Iwanicki M., Ukraińcy, Białorusini, Litwini i Niemcy w Polsce w latach 1918-1990, Siedlce 1991.

Jagiełło Z., Piechota Wojska Polskiego 1918-1939, Warszawa 2005.

Jarno W., Okręg Generalny WP nr III Kielce 1918-1921, Łódź 2003.

Kania L., Instytucja zwierzchnika sądowo-karnego jako dysponenta sądu polowego w Wojsku Polskim w latach wojen o granice Rzeczypospolitej 1918-1921, „Z Dziejów Prawa” 2020, t. 12.

Kania L., Klęska 1 BPRez. na Wołyniu w czerwcu 1920 r. w materiałach śledztwa prokuratorskiego, „Dzieje Najnowsze” 2019, nr 3.

Kania L., Organizacja i rys działalności sądów polowych Naczelnego Dowództwa Wojska Polskiego w przełomowym okresie wojny z Rosja sowiecka latem 1920 r., cz. 1, „Przegląd Historyczno-Wojskowy” 2018, nr 3/4 (265/266); cz. 2, „Przegląd Historyczno-Wojskowy” 2019, nr 1 (267).

Kania L., W cieniu Orląt lwowskich. Polskie sady wojskowe, kontrwywiad i stużby policyjne w bitwie o Lwów 1918-1919, Zielona Góra 2009.

Kania L., Wyroki bez apelacji. Sądy polowe w Wojsku Polskim w czasie wojny $z$ Rosja Sowiecka 1919-1921, Zielona Góra 2019.

Kasprzycki R., Dezercje i unikanie służby w WP w latach 1918-1939, „Dzieje Najnowsze" 2016, nr 3.

Klimaszewski K., Pakuła M., Bitwa Warszawska 1920 r. Jabłonna, Legionowo, Nieporęt, Serock, Wieliszewo, Legionowo 2016.

Krzemieński J., Wymiar sprawiedliwości w Wojsku Polskim, „Wojskowy Przegląd Prawniczy" 1928, nr 8-10.

Kukiel M., Dzieje Polski porozbiorowe 1795-1921, Paryż 1983.

Kuligowski J., Minsk Mazowiecki i okolice podczas Bitwy Warszawskiej 1920 r., „Rocznik Mińsko Mazowiecki” 2000, nr 6.

Kuligowski J., Pod okupacja sowiecką: (Mińsk w sierpniu 1920 r.), „Rocznik Mińsko Mazowiecki” 1996, nr 3.

Kulka G., Sąd honorowy dla generałów w Wojsku Polskim w latach 1918-1947, Oświęcim 2017.

Leczyk M., Oblicze społeczno-polityczne II Rzeczypospolitej, Warszawa 1988.

Malec D., Obywatelstwo państwa polskiego w świetle orzecznictwa Najwyższego Trybunału Administracyjnego 1922-1939, „Miscellanea Historico-Iuridica” 2015, t. XIV, z. 2.

Marszałek P. K., Wojskowy Gubernator Warszawy. Sierpień-wrzesień 1920 roku, „Acta Universitas Wratislaviensis”, nr 2616, „Prawo”, t. CCLXXXVIII, Wrocław 2004. 
Musialik Z. M., Wojna polsko-bolszewicka 1919-1920, Włocławek 1994.

Nowik G., Zanim złamano „Enigmę”. Polski radiowywiad podczas wojny z bolszewicka Rosja 1918-1920, Warszawa 2004.

Odziemkowski J., Piechota polska w wojnie z Rosja bolszewicka 1919-1920, Warszawa 2010.

Odziemkowski J., Wieś i armia w II Rzeczypospolitej, Wrocław-Warszawa-Kraków-Gdańsk-Łódź 1988.

Odziemkowski J., Wojsko Polskie w latach 1918-1920 (organizacja i struktura), Warszawa 2001.

Oleksiewicz W., Chłopi i ruch ludowy w obronie niepodległości Polski w 1920 roku, „Roczniki Dziejów Ruchu Ludowego” 1992, nr 27.

Orłowski M., Generał Józef Haller 1873-1960, Kraków 2007.

Ratajczyk G., Żandarmeria Wojska Polskiego II Rzeczypospolitej, Toruń 2004.

Rok 1920 na Podlasiu. Materiały z sesji popularno-naukowej zorganizowanej 10 XI 1990 r. w Białej Podlaskiej, red. H. Mierzwiński, Biała Podlaska 1990.

Rudnicki S., Żydzi w parlamencie II Rzeczypospolitej, Warszawa 2004.

Rybicki T., Sądownictwo polowe w latach wojny 1919-1921, „Wojskowy Przegląd Prawniczy" 1928, nr 8-10.

Smoliński A., Morale i dyscyplina Wojsk Wielkopolskich 1918-1919, Toruń 2009.

Stawecki P., Wskrzeszenie Wojska Polskiego na przełomie lat 1918 i 1919, „Studia i Materiały do Historii Wojskowości” 1986, t. XXIX.

Stawecki P., Z badań nad dyscypliną, przestępczościa i moralnościa wojska Drugiej Rzeczypospolitej, Warszawa 2000.

Suliński J., Dezercje w okresie międzywojennym, „Wojsko i Wychowanie” 1997, nr 3.

Suliński J., Żandarmeria organ bezpieczeństwa armii 1918-1945, Warszawa 2003.

Szczepański J., Społeczeństwo Polski w walce z najazdem bolszewickim 1920 roku, Warszawa-Pułtusk 2000.

Szczepański J., Wojna 1920 na Mazowszu i Podlasiu, Warszawa-Pułtusk 1995.

Szczepański J., Wojna 1920 roku w powiecie pułtuskim, Pułtusk 1990.

Szczepkowski M., Warszawski Okręg Generalny 1918-1921, „Rocznik Mazowiecki”, Warszawa 1984, z. 3.

Szczepkowski M., Zarys organizacji Wojska Polskiego na przełomie lat 1918 i 1919, „Wojskowy Przegląd Historyczny” 1990, nr 3/4 (133/134).

Witos W., Wybór pism, red. J. Borkowski, Warszawa 1989.

Wrzosek M., Wojsko Polskie i operacje wojenne lat 1918-1921, Białystok 1988.

Wyszczelski L., Warszawa 1920, Warszawa 1997.

Wyszczelski L., Wojna polsko-rosyjska 1919-1920, t. 1-2, Warszawa 2010.

Zając J., O podstawach karności wojskowej, Warszawa 1922.

Załęczny J., Wydarzenia wojny polsko-bolszewickiej 1920 roku na terenie ówczesnego powiatu warszawskiego, „Niepodległość i Pamięć” 2010, nr 2 (32).

Żarkowski P., Polska sztuka wojenna w okresie bitwy warszawskiej. Front Środkowy $w$ działaniach manewrowych $w$ sierpniu 1920 roku, Warszawa 2004. 


\section{STRESZCZENIE \\ Leszek Kania, Stosunek społeczeństwa polskiego i mniejszości narodowych do obowiązku służby wojskowej w czasie wojny z Rosją bolszewicką (luty 1919 - listopad 1920)}

Artykuł przedstawia zagadnienie ochrony zdolności bojowej oddziałów frontowych Wojska Polskiego przed ujemnymi zjawiskami obniżającymi ich morale i dyscyplinę w czasie wojny z Rosją bolszewicką w latach 1919-1921 oraz postawy społeczeństwa polskiego i mniejszości narodowych wobec spełnienia obowiązku służby wojskowej.

Po odzyskaniu niepodległości zaistniała konieczność stoczenia wojny o niepodległość i granice wschodnie z tradycyjnie agresywnym sąsiadem - Rosją bolszewicką - która chciała wykorzystać ograniczone możliwości zrujnowanego wojnami kraju, olbrzymie trudności wewnętrzne państwa scalonego z trzech dzielnic zaborczych, pozorną atrakcyjność ideologii bolszewickiej i wieloetniczność społeczeństwa, które częściowo stało się podatne na populistyczne hasła najeźdźcy. Wojsko Polskie trapiły w czasie tej wojny dezercje żołnierzy z linii bojowej i masowe uchylanie się od służby mężczyzn wezwanych do spełnienia obowiązku wojskowego wywodzących się z mniejszości narodowych. Oddziały walczące na froncie były poddane agitacji przez aparat propagandowy Armii Czerwonej, który chciał dokonać rozkładu moralnego Wojska Polskiego.

Słowa kluczowe: dyscyplina wojskowa, morale, przestępstwo, kontrwywiad, linia frontu

\section{SUM M A RY}

\section{Leszek Kania, Attitude of Polish Society and National Minorities towards Military Conscription During the War with Bolshevik Russia (February 1919-November 1920)}

The article is devoted to the protection of the combat capability of the Polish Army front troops from negative phenomena lowering their morale and discipline during the war with Bolshevik Russia in 1919-1921, and the attitudes of the Polish society and national minorities towards fulfilling their military service.

After regaining independence, the war for independence and eastern borders had to be fought with a traditionally aggressive neighbor, Bolshevik Russia, which wanted to take advantage of the limited capabilities of a country ruined by wars, the enormous internal difficulties of a state united from three partitioned districts, the apparent attractiveness of the Bolshevik ideology and the multi-ethnicity of the society, which to some extent became susceptible to the populist slogans of the invader. During this war, the Polish Army was troubled by desertion of soldiers from the battle line and by mass evasion of military duty by men with a national minority background. Units fighting at the front were agitated by the propaganda apparatus of the Red Army, whose intention was a moral decay of the Polish Army.

Keywords: military discipline, morale, crime, counterintelligence, front line 


\section{АННОТАЦИЯ}

\section{Лешек Каня, Отношение польского общества и национальных меньшинств к обязательной службе в армии во время войны с Большевистской Россией (февраль 1919-ноябрь 1920)}

В статье рассматривается проблема защиты боеспособности фронтовых подразделений Войска Польского от негативных явлений, снижающих их моральный дух и дисциплину во время войны с Большевистской Россией 1919-1921 гг., а также отношение польского общества и национальных меньшинств к выполнению воинской обязанности.

После возвращения независимости возникла необходимость вести войну за эту независимость и за восточные границы с традиционно агрессивным соседом, Большевистской Россией, желавшей воспользоваться ограниченными возможностями страны, разоренной войнами. Также она хотела использовать огромные внутренние трудности объединенного из трех разделенных территорий государства, очевидную привлекательность большевистской идеологии и многоэтничность общества, которое частично стало поддаваться популистским лозунгам оккупанта. Во время этой войны в Войске Польском бывали случаи дезертирства солдат на фронтовой линии и массовое уклонение от службы со стороны представителей национальных меньшинств, призванных исполнять свою воинскую обязанность. Войска, сражавшиеся на фронте, попали под влияние пропагандистского аппарата Красной Армии, который хотел довести Войско Польское до морального упадка.

Ключевые слова: воинская дисциплина, моральный дух, преступность, контрразведка, линия фронта 